\title{
Tumour vasculature targeting agents in hybrid/conjugate drugs
}

\author{
E.M. Prokopiou, S.A. Ryder and J.J. Walsh
}

School of Pharmacy and Pharmaceutical Sciences, Trinity College Dublin, Dublin 2, Ireland

E-mail: jjwalsh@tcd.ie

\author{
Note: This is an author-created version of an article accepted for publication in Angiogenesis following peer review.

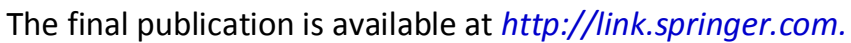 \\ Direct links to the definitive publisher-authenticated version [Prokopiou EM, Ryder SA, Walsh JJ. Tumour vasculature \\ targeting agents in hybrid/conjugate drugs. Angiogenesis. $2013 \mathrm{Jul} ; 16(3)$ : 503-24]: \\ http://link.springer.com/article/10.1007\%2Fs10456-013-9347-8 \\ http://dx.doi.org/10.1007/s10456-013-9347-8
}

\begin{abstract}
Tumour vasculature targeting has been a very active area of cancer drug discovery over the last decade. Growth of solid tumours beyond a certain point requires a sufficient blood supply in order for them to develop and metastasise. While novel anti-angiogenic and vascular disrupting agents represent an important contribution to the armoury of anti-cancer agents, they nevertheless usually require combination with standard cytotoxic therapy in order to demonstrate positive clinical outcomes. In line with this consensus, a new concept has arisen, namely the design of functional hybrids where at least one component of the design targets a tumour angiogenic/vasculature pathway. This review will outline examples of such hybrid/conjugate-based approaches. Emphasis will be placed on their preclinical evaluation with particular focus on the arginine-glycine-aspartic acid/asparagine-glycine-arginine (RGD/NGR) conjugates, heparin-related hybrids and antibodydrug conjugates. In conclusion, the benefits and shortcomings of hybrids under development will be discussed in the context of future directions and applications.
\end{abstract}

Keywords Angiogenesis $\bullet$ Combination therapy $\bullet$ Conjugates $\bullet$ Hybrids $\bullet$ Tumour vasculature $\bullet$ Vascular disrupting agents

\section{Angiogenesis}

Angiogenesis is defined as the process in which new blood vessels form from the existing vasculature [1]. During this process, endothelial cell proliferation is induced, which results in alignment of endothelial cells into capillary tubes (vasculogenesis). Physiologically, this process takes place during embryogenesis and the female reproductive cycle, as well as in wound healing. During tumour angiogenesis, the "angiogenic switch" is turned on causing the normally quiescent vasculature to constantly sprout new vessels, thus facilitating tumour growth [1,2]. As evident from earlier in vivo work in rabbits with implanted tumours and non-tumour tissue in non-vascularised cornea, tumour growth was shown to be angiogenesis-dependent. Tumour tissue was able to grow once newly formed vasculature was developed, whereas nontumour tissue did not attract new blood vessels [3]. Angiogenesis is a complex process which involves a number of steps including the production and release of angiogenic factors (upon activation by hypoxia or genetic mutations) [4-6], and the binding of these factors to vascular endothelial cell receptors, causing activation and cell proliferation. Extracellular metalloproteinases mediate many of the changes in the microenvironment by degrading the extracellular matrix (ECM) in front of the proliferating endothelial cells [7]. Endothelial cells then subsequently migrate towards the tumour tissue where they align to form new blood vessels and connect to create a loop that allows the blood to circulate. Specialised muscle cells (e.g. smooth muscle cells and pericytes) stabilise the vessel tubes providing structural support [8].

\section{Angiogenic regulators}

Many endogenous molecules are involved in the control of angiogenesis and several of these have been studied for potential therapeutic applications. Pro-angiogenic regulators include vascular endothelial growth factors (VEGFs), fibroblast growth factors (FGFs), platelet-derived growth factors (PDGFs), epidermal growth factors (EGFs) and their associated tyrosine kinase receptors, VEGFRs, FGFRs, PDGFRs and EGFRs and matrix metalloproteinases (MMPs).

Endogenous angiogenesis inhibitors include thrombospondin-1 (TSP-1), angiostatin, endostatin, tumstatin and canstatin. TSP-1 counteracts pro-angiogenic stimuli by evoking suppressive signals through activation of endothelial cell receptors [9]. Angiostatin and endostatin are produced in the tumour stroma through the action of proteinases which are induced as part of the angiogenic cascade [10]. Angiostatin (an internal fragment of plasminogen containing at least three of the kringles of plasminogen) was shown to be inversely correlated with VEGF and inhibited endothelial cell migration, tube formation and aortic ring sprouts [11]. In an in vivo assay, angiostatin was found to maintain metastases in a dormant state when administered exogenously [12] and was associated with longer patient survival [13]. A Phase II trial using recombinant 
human angiostatin (hAngiostatin) in combination with paclitaxel and carboplatin resulted in a high disease control rate in patients with advanced non-small cell lung cancer (NSCLC) [14]. While angiostatin has shown clinical potential, a significant disadvantage with this agent is its short half-life ( $15 \mathrm{~min})$, leading to a need for continuous administration $[15,16]$.

Endostatin (C-terminal fragment of collagen XVIII) has also shown anti-angiogenic activity in vitro by suppressing VEGFinduced tyrosine phosphorylation of VEGFR-1/2, as well as overall VEGFR-2 expression and the activation of extracellular signal-regulated kinase (ERK), p38, mitogen activated protein kinase (MAPK) and Akt in human umbilical vein endothelial cells (HUVECs) [17]. Treatment with endostatin resulted in inhibition of proliferation, migration, and tube formation of endothelial cells, resulting in inhibition of angiogenesis and tumour growth [18, 19]. Endostatin inhibited primary tumour growth of NSCLC, Lewis lung carcinoma and B16F10 melanoma, and maintained metastasis in a dormant state, without exhibiting apparent side effects [20-23]. In China, endostatin (Endostar ${ }^{\mathrm{TM}}$ ) has been approved for the treatment of NSCLC [24]. The urine levels of endostatin and VEGF were proven to be clinically useful in the diagnosis of bladder cancer, and endostatin but not VEGF, was shown to be a supplementary prognostic marker for predicting tumour progression [25]. In addition, high levels of endostatin were associated with poor survival of patients with advanced-stage nasopharyngeal carcinoma [26]. Although the mechanism associated with high levels of endostatin and poor clinical outcome is unclear, the elevation of endostatin in particular cancer types, such as the nasopharyngeal carcinoma, might be a result of increased tumour angiogenesis, which reflects in tumour burden. In addition, increased serum endostatin concentration may indicate unidentified micro-metastatic disease.

Tumstatin ( $\alpha 3$ chain, type IV collagen, NC1 domain; $\alpha 3($ IV)NC1) mediates its anti-angiogenic activity by interaction with the $\alpha_{v} \beta_{3}$ integrin in an RGD (arginine-glycine-aspartic acid)-independent manner [27] and inhibits protein synthesis specifically in endothelial cells [28]. Tumstatin's therapeutic potential was studied in a number of tumour models, including human prostate and renal cell carcinoma (RCC) $[29,30]$, as well as laryngeal squamous carcinoma xenografts [31]. Studies conducted by Luo et al. [32] demonstrated that tumstatin-mRNA expression level correlates with prognosis in NSCLC, suggesting that tumstatin-mRNA may be a potential marker of a favourable prognosis in NSCLC. It was identified that a peptide composed of residues 45-132 of $\alpha 3$ (IV)NC1 fragment was sufficient to inhibit in vitro and in vivo angiogenesis through induction of apoptosis [27]. Thus, further tumstatin-related peptides were synthesised and demonstrated antiangiogenic and anti-tumour effects [33-35].

Canstatin (NC1 domain of the $\alpha 2$ chain of type IV collagen) was shown to inhibit endothelial cell migration, capillary tube formation and suppression of tumour growth in prostate, RCC, squamous cell carcinoma (SCC), pancreatic and breast cancer xenograft models [36-39]. In addition, canstatin inhibited Akt activation, induced Fas-dependent apoptosis in endothelial cells [40] and inhibited angiogenesis and lymphangiogenesis via suppression of the integrin-dependent focal adhesion kinase (FAK) signalling (induced by angiopoietin-1/Tie-2 and/or VEGFR-3) [41]. Xing et al. [42] demonstrated that the antitumour activity of exogenous and endogenous canstatin was greater than either treatment alone in colorectal cancer cells.

The expression of these factors can be induced by environmental stress including glucose deprivation, formation of reactive oxygen species, cellular acidosis and iron deficiency, by the loss of the function of tumour-suppressor genes or by the activation of oncogenes [43-45]. Simple changes in the relative balance of inducers and inhibitors of angiogenesis can activate the "angiogenic switch". Furthermore, newly characterised ligands of signal-transducing receptors which are displayed by endothelial cells include notch, neuropilin, robo and ephrin Eph-A/B receptors. These pathways have been shown to be associated with developmental and tumour-driven angiogenesis, demonstrating the complexity of endothelial cell regulation [46-49].

\section{Tumour vasculature}

Morphologically, anatomically and functionally, tumour vasculature differs from the normal vasculature and is associated with an abnormally increased rate of angiogenesis. This is particularly so in undeveloped tumour blood vessels which are often distinguished by their abnormal characteristics including fragility, chaotic arrangements, imperfect vessel walls due to discontinuous endothelial cell lining and weak investiture with vascular smooth muscle cells. Additionally, there are poor connections between pericytes and endothelial cells which themselves are usually irregularly shaped, forming an uneven luminal layer with loose interconnections and focal intercellular openings [50-53]. Tumour blood vessels have an irregular, structurally abnormal basement membrane $[54,55]$, uneven diameter and very long distance between branching points, which results in a chaotic vascular network with complex branching patterns and lack of hierarchy [56-58]. These characteristics of the newly developed tumour vasculature allows for macromolecule diffusion, aid the metastatic process by facilitating the tumour cells into the bloodstream and accumulates fibrin in the ECM, therefore favouring angiogenesis. The histological grade and malignant potential of the tumour normally correlates with the degree of blood vessel leakiness [59].

\section{Why target the tumour vasculature?}

The ability to selectively target established tumour vasculature is a very appealing strategy for the treatment of cancer, which allows rapid vascular shutdown, leading to secondary tumour cell death. The differences between tumour and normal blood vessels described earlier might be the reason why tumour vasculature is more susceptible to vascular disrupting agents (VDAs) than normal vasculature. These types of agents have several advantages over conventional chemotherapeutic agents as the therapy is effective in the majority of solid tumours, regardless of histological sub type. 
Killing of relatively few vascular endothelial cells is likely to result in the death of a large area of tumour via widespread central necrosis whereas direct targeting of tumour cells require all cells to be killed in order for the therapy to be effective. VDAs also have the ability to avoid undesirable acquired drug resistance as they target normal vascular endothelial cells which are considered more genetically stable than tumour cells. An additional advantage is that drug delivery to cellular targets lining blood vessels is easier to achieve compared with targets in the tumour area distant from capillaries [60].

Intuitively, there are two different approaches that may be used to cause disruption of the blood supply to the tumour: targeting tumour angiogenesis or the established tumour vasculature. Clinically, the most promising are the antiangiogenics represented by the family of monoclonal antibodies and small molecule based tyrosine kinase inhibitors (TKIs). The monoclonal antibodies are designed either to bind to the extracellular domains of the over-expressed receptors or to inhibit angiogenic regulators, including bevacizumab (Avastin ${ }^{\circledR}$ ) [61] and trastuzumab (Herceptin ${ }^{\circledR}$ ) [62]. Multi-TKIs are $^{2}$ designed to target the intracellular tyrosine kinase domain of the receptors and these include sunitinib (Sutent ${ }^{\circledR}$ ) [63], sorafenib (Nexavar ${ }^{\circledast}$ ) [64] and pazopanib $\left(\right.$ Votrient $\left.^{\circledR}\right)$ [65], with more recent developments in this area contained in a review by Gotink et al. [66].

Although small molecule VDAs are not specific to tumour vessels, they exploit pathophysiological differences between normal and tumour tissue endothelium to achieve tumour vessel selectivity. Perhaps the best known class of VDAs are the tubulin targeting agents which have both anti-mitotic and anti-vascular effects, leading to inhibition of spindle formation (mitotic arrest) and reduced tumour blood flow, respectively [67]. The earliest tubulin binding agents which demonstrated anti-mitotic and anti-vascular activity included colchicine [68], the vinca alkaloids e.g. vincristine (Oncovin ${ }^{\circledR}$ ) [69] and the taxanes e.g. paclitaxel $\left(\mathrm{PTX}\right.$, Taxol $\left.^{\circledR}\right)$ [70]; however these compounds have a very narrow therapeutic window associated with consequent dose limiting toxicities (DLTs) [71, 72].

The first small molecule VDA that was shown to have anti-vascular effects at doses below the maximum tolerated dose (MTD) was combretastatin A-4 (CA-4) [73], a tubulin binding agent with structural similarities to colchicine that was isolated from the Cape bushwillow tree, Combretum caffrum [74, 75]. CA-4 treatment has been shown to cause extensive tumour vascular damage and necrosis in vivo at relatively non-toxic doses [73]. A more soluble disodium phosphate (CA-4P) prodrug form has been developed. CA-4P is rapidly cleaved by endogenous non-specific phosphatases to release the active CA-4 [76]. Pre-clinical studies in mouse and rat tumour models demonstrated that CA-4P was able to cause rapid tumour vascular shutdown and reduce blood flow at doses well below the MTD, offering a wide therapeutic index [73], while normal tissue was much less affected [77, 78]. The vascular shutdown induced by CA-4P in tumours is due to the change in shape of newly formed endothelial cells [79], causing microtubule breakdown and reorganisation in the actin cytoskeleton, resulting in membrane blebbing [80]. CA-4P completed Phase I and II clinical trial evaluation in patients with advanced solid tumours such as anaplastic thyroid cancer and lung cancer, and is undergoing Phase III trials in combination with conventional chemotherapy/radiotherapy against a variety of tumour types [75, 81-84].

\section{Anti-angiogenic treatment and vasculature normalisation}

An additional rationale for the use of anti-angiogenic therapy suggests that treatment with these agents can result in a more "normal" vasculature that is more conducive to the delivery of nutrients and therapeutics. This may be especially advantageous as tumour hypoxia results in tumour cell resistance to radiotherapy or cytotoxic agents and induces genetic instability [85]. Previous studies have shown that anti-angiogenic treatment resulted in vascular normalisation by blocking of VEGF or its receptor VEGFR2, leading to endothelial cell apoptosis and a reduction in vessel diameter, density and permeability [86-88]. Subsequently, interstitial fluid pressure decreased and, in some tumours, oxygen tension increased [89, 90]. Taking into consideration that anti-angiogenic drugs are normally combined with other chemotherapeutic agents [91], it is still unclear whether the effect of these agents occurs as a result of vascular normalisation [92]. A better understanding of the molecular mechanism of vascular normalisation may lead to more efficient anti-cancer therapies as well as treatments for other vascularrelated diseases. A more comprehensive review on this subject is presented by Jain [93].

\section{Combination therapy with VDAs and anti-angiogenics}

Single agent administration of VDAs can cause massive central tumour necrosis due to vascular collapse; however a narrow viable rim on the periphery of tumour tissue often remains, allowing tumour cells to repopulate and avoiding complete tumour cell death. A possible explanation for this is that the peripheral tumour cells can obtain oxygen and nutrients from the surrounding non-tumour blood vessels, which are less responsive to VDAs [94, 95]. The tumour periphery is the only tumour region that is easily accessible to therapeutic agents, leading to the suggestion that the optimal clinical use of VDAs would be in combination with other treatments, including cytotoxic chemotherapy/radiotherapy. In this way, the remaining viable rim of the tumour may be eliminated, eventually causing total tumour cell death [95-98]. Use of current antiangiogenic treatments alone has provided only a modest survival benefit, thus interest in combining anti-angiogenic drugs with conventional cytotoxic chemotherapies as this has been shown to maximise the effect of therapies. For instance, bevacizumab has been approved in combination with a 5-fluorouracil-based (5-FU) regimen, for first and second-line treatment of patients with metastatic colorectal carcinoma [99], while a recent Phase I clinical trial showed that treatment with CA-4P, a VDA, in combination with bevacizumab resulted in profound tumour vascular changes [100]. 


\section{Hybrid drugs}

A relatively new approach which has emerged in the last decade is the design of hybrid based therapies using different modalities. Two or more targeting ligands are joined together with a linker to form one individual compound, called a hybrid. Walsh and Bell [101] have discussed the concept of hybrid based approaches for malaria, while Chow and Chan [102] have outlined the concept of hybrid based anti-tumour drug candidates. This concept is based on the premise that drugs in hybrid form may overcome the disadvantages associated with monotherapy or indeed combination chemotherapy in terms of drug resistance, pharmacokinetics and solubility concerns associated with the individual constituents. In addition, the effect of the hybrid drug could be synergistically greater than the free agents. Most importantly, selectivity could be vastly improved because VDAs which have been examined so far have demonstrated a lack of selectivity. In this respect, one component of the hybrid drug could act as a tumour-homing device in order to target specifically tumour vessels while the other component may be the active agent $[103,104]$. Other design strategies that can be adopted include presenting both moieties in active form, one component of the hybrid in prodrug form or both moieties in prodrug form, giving an overall pro-prodrug. Frequently, hybrids depend upon specific enzymes or chemical transformation to release their two components as active agents; in this way systemic toxicity may be reduced and drug delivery may be optimised to the target site [105].

Nevertheless, administration of hybrid based inhibitors may have a reduced effect compared to the combination of single constituents, perhaps because of the increased bulk of the molecule which may decrease penetration to the target site. Combination treatment with individual drugs should be examined at an early stage and then compared to the hybrid in order to observe any potential benefits or drawbacks of the hybrid over the individual components.

\section{Hybrid approaches}

A variety of hybrid designs have been proposed and evaluated for use as anti-cancer agents, revealing their benefits in drug delivery as well as their inherent associated complexity. Such designs include hybrids/conjugates with either one or both components aiming to inhibit tumour angiogenesis or disrupt the existing tumour vasculature. Rejniak et al. [106] have published a review on hybrid models of tumour growth emphasising the mathematical modelling approaches that can handle multiple intracellular and extracellular factors, and assist in the design of hybrid molecules.

In this review, an overview of the preclinical evaluation of hybrids/conjugates designed to target tumour angiogenesis and vasculature will include: (1) arginine-glycine-aspartic acid/asparagine-glycine-arginine (RGD/NGR) related conjugates, (2) heparin-associated conjugates, (3) tubulin targeting-cytotoxic hybrids, (4) antibody-drug hybrids and (5) toxin-drug hybrids (Fig. 1).

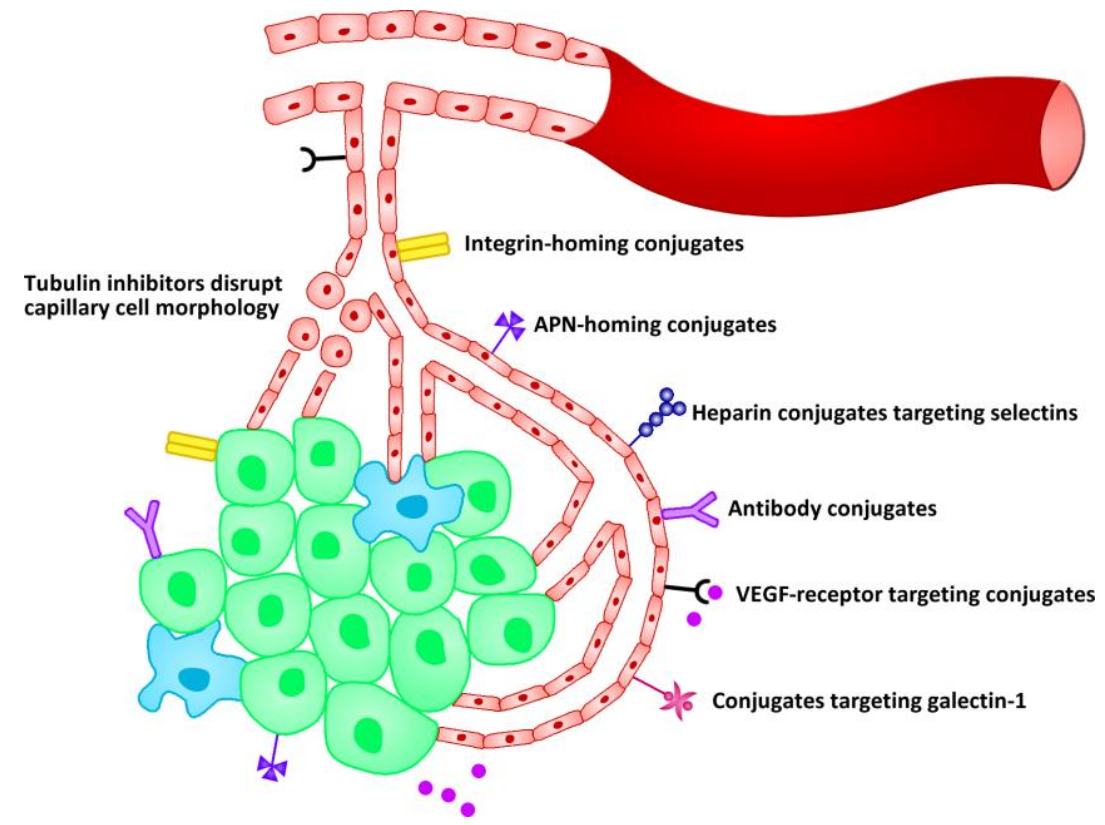

Figure 1 Hybrid targets on tumour vasculature: integrins [104, 117-121, 127, 128, 142, 150], APN [104, 133-141, 146, 147], selectins [161, 168, 171, 173, 175-179, 184, 185], tubulin [186, 187, 190], antigens [196-198, 204, 205], VEGFR [219, 223] and galectin-1 [232]

\section{RGD/NGR-related hybrids}

Targeted delivery of cytotoxic agents to the tumour vasculature may be achieved by the identification of molecular markers that differentiate newly formed capillaries from mature vessels. Integrins are heterodimeric transmembrane proteins that represent a family of over $15 \alpha$ and $8 \beta$ subunits which can heterodimerise to form over 20 combinations. A single ECM ligand could be recognised by different integrin combinations, while others may recognise several different ECM proteins. Integrin-mediated adhesion induces intracellular signalling pathways that modulate cell survival, proliferation and migration [107]. These signals involve phosphorylation of non-receptor tyrosine kinases (such as focal adhesion kinase and Src 
kinases), inositol lipid synthesis and elevation in intracellular calcium and $\mathrm{pH}$. Consequently, a number of downstream signals are triggered, including activation of the Ras/MAPK pathway [107]. Activated endothelial cells express several types of integrins on their surface during angiogenesis, which regulate critical adhesive interactions with several ECM proteins such as fibronectin, vitronectin, laminin, fibrinogen, von Willebrand factor, collagen types I and IV and denatured collagen. Cell migration, proliferation and differentiation are distinct biological events which are regulated by these adhesive interactions and which are involved in the process of angiogenesis [108]. An interesting expression pattern has been identified by integrin $\alpha_{v} \beta_{3}$ with an exposed RGD sequence on endothelial cells undergoing angiogenesis in tumours, wound healing or inflammatory tissues, and this might be a useful diagnostic or prognostic indicator of tumours [109-112].

One of the best known and specific markers is the $\alpha_{v} \beta_{3}$ integrin which mediates the attachment of endothelial cells to submatrix proteins such as vitronectin, which forms the capillaries' basement membrane [113]. The $\alpha_{v} \beta_{3}$ integrin is found on the luminal surface of the endothelial cells only during angiogenesis and vascular remodelling [110, 114], although all endothelial cells use the integrin to attach to the extraluminar sub-matrix. Phage display studies have distinguished a selective ligand sequence RGD which has high affinity for the $\alpha_{v} \beta_{3}$ integrin [115]. The tissue distribution of $\alpha_{v} \beta_{3}$ integrin is limited in adults but it is expressed on a small percentage of activated macrophages, leukocytes and osteoclasts, where it appears to be involved in bone resorption and immune function. The $\alpha_{v} \beta_{3}$ integrin is also expressed in some invasive tumours, such as late-stage glioblastomas and metastatic melanomas, leading to the malignant phenotype of the tumour [116]. Previous studies suggested that $\alpha_{v} \beta_{3}$ integrin may serve as an effective diagnostic or prognostic indicator of malignancies.

\section{PTX-RGD conjugate}

In order to increase selectivity to tumour blood vessels, different studies have used several chemotherapeutic agents linked to the RGD peptide. Chen et al. designed a dimeric RGD peptide $E[c(R G D y K)]_{2}$, a potent $\alpha_{v}$-integrin antagonist, as a carrier for PTX in order to specifically target tumour vasculature and breast cancer cells. RGD peptide inhibited cell cycle proliferation by $\mathrm{G}_{0} / \mathrm{G}_{1}$-phase arrest, whereas the PTX-RGD conjugate 1 , showed inhibition of cell proliferation mediated by a $\mathrm{G}_{2} / \mathrm{M}$-phase cell cycle arrest followed by apoptosis, and its activity was comparable to that observed for PTX. The integrin binding affinity of 1 was slightly reduced compared to the unconjugated peptide; however there was specific accumulation of the conjugate in integrin-expressing sites in vivo. The highest tumour uptake of ${ }^{125}$ I-labeled PTX-RGD was observed after $2 \mathrm{~h}$ post-injection and the best tumour/background contrast after $4 \mathrm{~h}$ post-injection. These results demonstrated the potential of the conjugate to be delivered specifically to integrin-rich sites of the tumour and the vasculature, thereby reducing toxicity and improving selectivity [117]. In another study, PTX was conjugated with a divalent cyclic peptide E[c(RGDfK $)_{2}$ ], which is a novel ligand-based vascular targeting agent that binds to $\alpha_{v} \beta_{3}$ integrin, and showed high uptake in OVCAR-3 xenograft tumours [118]. Promising results were observed in vitro, although the PTX conjugate was inactive in vivo following intravenous (i.v.) administration in an ovarian cancer xenograft model. A possible reason suggested by the authors which could explain the lack of efficacy of the PTX conjugate in vivo, was premature release of PTX into the circulation and thus reduced accumulation of the active drug at the tumour site [119]. Nevertheless, as PTX is a well known anti-cancer agent one might still have expected a small degree of anti-tumour activity. Perhaps a more likely outcome is extensive metabolism of the conjugate to inactive metabolites in vivo (Fig. 2).

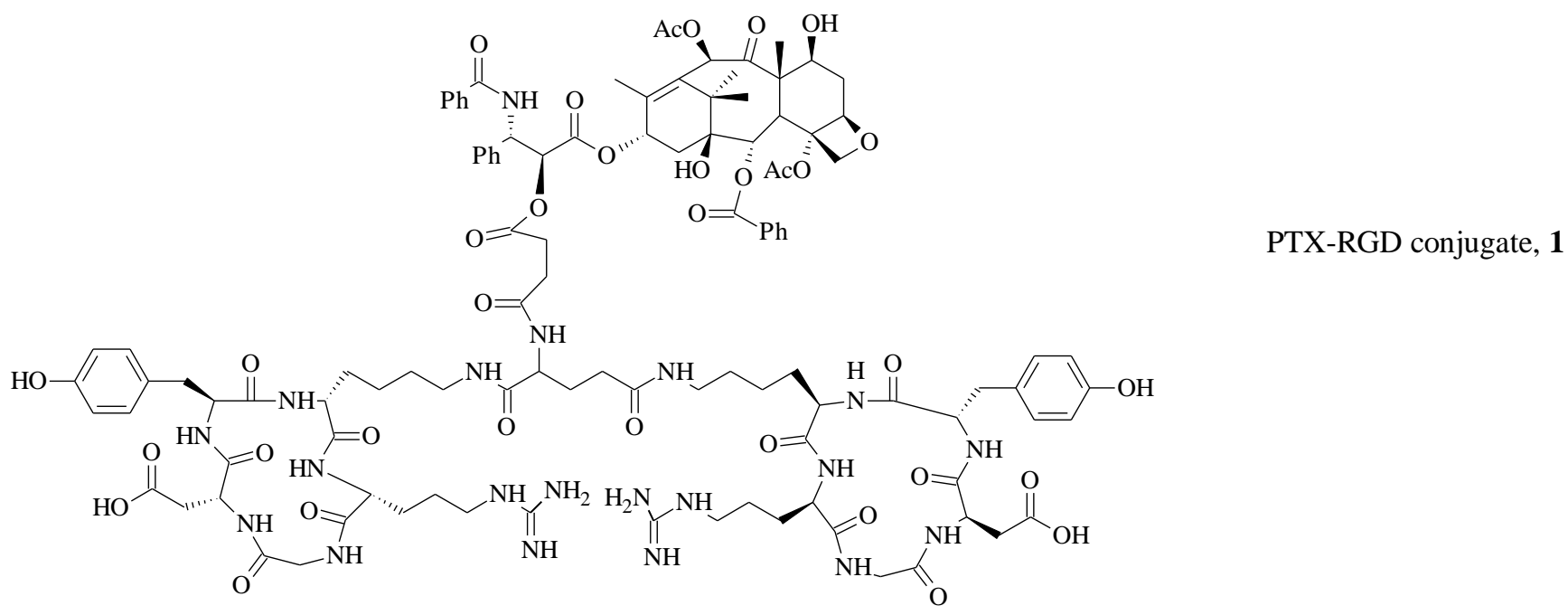

Figure 2 PTX-RGD conjugate, 1 [117]

\section{MMAE-HSA-RGD hybrid}

The tubulin targeting agent monomethyl auristatin $E$ (MMAE) was bound via the valine-citrulline linker to human serum albumin (HSA), which is a biocompatible and biodegradable carrier. Conjugation of cRGD peptides to MMAE-HSA was established either by a polyethylene glycol (PEG) linker or a short alkyl linker, in order to promote selectivity to angiogenic endothelial cells. Both conjugates inhibited the proliferation of HUVECs at nM concentrations and displayed excellent tumour homing properties upon i.v. administration in C26 tumour models [120]. It is worth noting that no control 
compounds such as MMAE were examined in order to better define the conjugates' activity. Furthermore, MMAE prodrug, which recruits tumour-associated protease legumain for its activation, was designed to target cell surface $\alpha_{v} \beta_{3}$ integrin. MMAE conjugate strongly induced cell death of MDA-MB-435 breast cancer cells which are positive for $\alpha_{v} \beta_{3}$ integrin expression. Treatment of tumour bearing mice with $3 \mathrm{mg} / \mathrm{kg}$ every 3 days for 17 days resulted in decreased tumour growth and metastasis in 4T1 murine breast cancer, D121 Lewis lung carcinoma and MDA-MB-435 models. These findings suggest that MMAE's activity was enhanced by selective targeting of integrin-rich sites and legumain protease on tumour cells, which otherwise would be too toxic to use for therapeutic applications at the dose evaluated [121].

\section{sFlt-1 gene-PEI-g-PEG-RGD conjugate}

Gene therapy is a different strategy which selectively aims to target tumour vasculature by inhibiting angiogenesis. Several studies have described RGD-mediated gene delivery systems for transferring siRNA [122] or luciferase reporter gene [123]. A study conducted by Kim et al. reported a therapeutic gene encoding Flt-1 (fms-like tyrosine kinase-1) and evaluated its anti-angiogenic activity when conjugated to PEI-g-PEG-RGD (polyethylenimine with a hydrophilic PEG spacer) gene carrier. Flt-1 is a VEGFR which upon activation leads to endothelial cell stimulation, proliferation, migration and capillary tube formation [124]. Soluble Flt-1 (sFlt-1) impairs the action of VEGF. Although the transmembrane and intracellular tyrosine kinase domains are absent, sFlt-1 binds to VEGF with the same affinity and specificity as that of the full-length receptor [125]. The PEI part of the conjugate could increase the transfection efficiency by avoiding degradation of DNA complexes from endosome or lysosome compartments [126], and the PEG could decrease the cytotoxicity and increase the solubility of the conjugate. The results of this study showed that the complex of sFlt-1 gene with PEI-g-PEG-RGD conjugate effectively and selectively inhibited endothelial cell proliferation, by blocking the binding of VEGF to the actual Flt-1 receptor [127].

Further studies evaluated the effect of repeated treatment with the conjugate in vivo which resulted in anti-tumour activity and an increased survival rate; however the effect was not identified in PEI-g-PEG/pCMVsFlt-1 or PEI-g-PEG-RGD/pCMV-GFP control groups. These findings suggest the use of a non-viral gene carrier to deliver an anti-angiogenic gene at a low continuous dosage, where it is not possible to use other vectors [128].

\section{Tumour necrosis factor- $\alpha$ associated RGD/NGR conjugates}

Corti and Ponzoni have described three strategies which use tumour necrosis factor- $\alpha$ (TNF- $\alpha$ ) to increase the local concentration of chemotherapeutic agents at the tumour site. TNF- $\alpha$ is an inflammatory cytokine which increases vascular permeability [129] and is cytotoxic to several tumour cell lines. It induces haemorrhagic necrosis in certain solid tumours and has also shown significant anti-tumour activity in animal models $[130,131]$. Despite its success in vivo, the use of TNF- $\alpha$ therapy in the clinic has been limited due to systemic toxicity.

To address this concern, different approaches were introduced, the first one using TNF- $\alpha$ before the administration of chemotherapy in order to increase vascular permeability and enhance the diffusion of the anti-cancer agent into the tumour. The second strategy was based on targeting aminopeptidase N (APN/CD13) present on blood vessels undergoing angiogenesis but not quiescent vessels [132], by coupling TNF- $\alpha$ to the peptide CNGRC (asparagine-glycine-arginine). The NGR-TNF- $\alpha$ conjugate showed increased leakage of the vasculature in the treated murine lymphomas compared to the controls. Immunohistochemical analysis revealed decreased tumour hypoxia, as well as elevated tumour blood flow, $2 \mathrm{~h}$ after treatment. Interestingly, reduction in tumour hypoxia did not lead to additional tumour growth; however the tumour volume decreased within $24 \mathrm{~h}$ following conjugate administration [133]. A Phase I clinical study was conducted with the conjugate to determine its DLTs, MTD and its anti-tumour activity in patients, as well as to examine the vascular response determined by dynamic contrast-enhanced magnetic resonance imaging (DCE-MRI). NGR-TNF- $\alpha$ was well tolerated and the results from DCE-MRI confirmed the anti-vascular effect of the agent. Approximately one-third of the patients experienced stable disease; however no objective responses were observed [134, 135]. A further trial was conducted using NGR-TNF- $\alpha$ as a single agent in hepatocellular carcinoma (HCC) patients and was well tolerated, with only mild to moderate chills reported as side effects. The overall response rate was $7 \%$, while $22 \%$ of the patients had stabilised disease [136]. Currently, there are several completed and ongoing Phase II clinical trials with the NGR-TNF- $\alpha$ conjugate as a single agent or in combination therapy for the treatment of mesothelioma, colorectal, liver and ovarian cancer [137-139]. Phase III studies have commenced evaluating its effect in patients with malignant pleural mesothelioma [140].

The third strategy worthy of consideration here, although not a true hybrid, was to examine the biological effects of doxorubicin (DOX)-encapsulated liposomes coupled with the NGR motif. Improved drug uptake by neuroblastoma tumours and enhanced therapeutic efficacy were observed using DOX-encapsulated liposomes homing to tumour vessels [141]. This strategy could prove effective in poorly vascularised tumours where it is harder for therapeutic agents to reach.

In other studies relating to TNF- $\alpha$, Tandle et al. have reported a hybrid adeno-associated virus phage (AAVP) vector that was used to target tumour endothelium with TNF- $\alpha$. The AAVP vector targets gene products to tumour vasculature by using the RGD4C peptide. Human melanoma cells were infected with AAVP-TNF- $\alpha$ and resulted in high expression levels of TNF- $\alpha$, while systemic administration of the RGD-AAVP-TNF- $\alpha$ conjugate to melanoma xenografts produced targeted delivery of the virus to the tumour vasculature; notably, the non-targeted vector was not delivered specifically to tumour vessels. The RGD-AAVP-TNF$\alpha$ vector enhanced delivery of TNF- $\alpha$ to the tumour vasculature resulting in induction of apoptosis in tumour vasculature and significantly reduced tumour growth, without observable organ toxicity. Therefore, this approach could be useful to target tumour vasculature by delivering anti-cancer agents directly to integrin-expressing tumour angiogenic sites [142]. 


\section{5-Fluoro-2-deoxyuridine CNGRC conjugate}

Furthermore, Zhang et al. reported the design and synthesis of two prototypes of tumour targeting 5-fluoro-2-deoxyuridine (5-FdUrd) prodrugs conjugated with a CNGRC by known linkers based on succinate and glutarate esters. 5-FdUrd is a cytotoxic anti-cancer drug which mediates its action by blocking thymidylate synthase to inhibit DNA synthesis and incorporation of its metabolites into DNA or RNA $[143,144]$. However, treatment with this agent is associated with various side effects including non-specific toxicity toward normal tissues [145]. Both conjugates exhibited lower cytotoxicity compared to 5-FdUrd, showing selectivity towards APN-positive cells over APN-negative cells [146]. Although these conjugates were not evaluated in vivo, the expectation would be an observable improvement in both efficacy and toxicity associated with these conjugates over 5-FdUrd, especially in tumour types that express high levels of APN.

\section{Platinum-based RGD/NGR conjugates}

Platinum (Pt)-based drugs, such as cisplatin, have been conjugated to peptide motifs containing RGD, NGR, CRGDC and (RGDdK)c. Mukhopadhyay et al. reported that the Pt(IV)-RGD conjugates $\mathbf{2 a}$ and $\mathbf{2} \mathbf{b}$ were highly and specifically cytotoxic to endothelial cells and $\alpha_{v} \beta_{3} / \alpha_{v} \beta_{5}$-expressing cell lines, approaching the activity of cisplatin. The Pt(IV)-NGR complexes $3 a$ and 3b were less active than the Pt(IV)-RGD conjugates, but nevertheless showed higher activity compared to the control complexes [104]. The difference in activity of these conjugates could be due to the expression patterns of APN and integrins in the cell lines used (Fig. 3).<smiles>[X]C(=O)CCC(=O)OP(N)(N)(Cl)OC(=O)CCC(=O)O</smiles>

$\mathbf{a}$<smiles>[X]C(=O)CCC(=O)O[P+](N)(N)OC(=O)CCC([X])=O</smiles>

b
$\mathrm{X}=\mathrm{RGD}=\mathbf{2} \mathbf{a}, \mathbf{2} \mathbf{b}=\mathrm{Pt}(\mathrm{IV}) \mathrm{RGD}$ conjugate $\mathrm{X}=\mathrm{NGR}=\mathbf{3} \mathbf{a}, \mathbf{3} \mathbf{b}=\mathrm{Pt}(\mathrm{IV}) \mathrm{NGR}$ conjugate

\section{Figure $\mathbf{3} R G D$ and NGR platinum-based conjugates, $2 \boldsymbol{a}, \mathbf{2} \boldsymbol{b}$ and $\mathbf{3 a}, \mathbf{3} \boldsymbol{b}$ [104]}

Although not studied directly in a tumour angiogenesis environment, Ndinguri et al. synthesised a Pt-based conjugate, cyclic mPEG-CNGRC-Pt and a dichloro(ethylenediamine)platinum(II) (PtenCl2) based conjugate, cyclic mPEG-CNGRC-Pten. Selective delivery of these conjugates was observed in APN-positive PC-3 cells and these agents exhibited significantly higher activity over untargeted carboplatin. Further analysis on the effects of these conjugates on PC-3 cells was determined using caspase-3 and -7 activation, fluorescence microscopy and DNA fragmentation, which confirmed the induction of apoptosis [147]. As this targeting approach was effective against APN-positive cell lines, one might expect a similar translational effect with these agents against proliferating endothelial cells and indeed angiogenic environments.

Hybrid-based strategies that incorporate a RGD/NGR homing ligand have comprised an active area of recent research in this field. What is presented here is a snapshot of the area. A more comprehensive review of the RGD-conjugates has been presented by Temming et al. [148] who concentrate on the structural requirements for RGD-peptides and RGD-mimetics as ligands for $\alpha_{v} \beta_{3}$, while an additional review by Corti et al. [149] focuses on structural and functional properties of the NGR motif and its applications in anti-angiogenic therapeutics (Table 1).

Table 1 Summary of the RGD/NGR-related hybrids

\begin{tabular}{|c|c|c|c|c|}
\hline Moiety A & Moiety B & Linker & Activity & References \\
\hline RGD & PTX & Succinate & $\begin{array}{l}\text { Inhibition of cell proliferation, slightly reduced integrin binding activity. } \\
\text { Specific accumulation of integrin in vivo. }\end{array}$ & {$[117-119]$} \\
\hline RGD & MMAE-HAS & Valine-citrulline & Growth inhibition of HUVECs and tumour homing properties in vivo. & {$[120]$} \\
\hline PEI-g-PEG-RGD & sFlt-1 & Amide & $\begin{array}{l}\text { Selective inhibition of endothelial cells' proliferation. Anti-tumour } \\
\text { activity and increased survival rate in vivo. }\end{array}$ & {$[127,128]$} \\
\hline RGD-4C & AAVP-TNF- $\alpha$ & - & $\begin{array}{l}\text { Targeted delivery to tumour vasculature, induction of apoptosis, and } \\
\text { significantly reduced tumour growth. }\end{array}$ & {$[142]$} \\
\hline NGR & TNF- $\alpha$ & - & $\begin{array}{l}\text { Increase of vascular permeability and anti-tumour effect in vivo. } \\
\text { Successful completion of Phase I and II trials as a single agent or in } \\
\text { combination therapy. Currently undergoing evaluation in Phase III } \\
\text { clinical trial for the treatment of malignant mesothelioma. }\end{array}$ & {$[133-139,141]$} \\
\hline RGD & CA-4/DOX & - & $\begin{array}{l}\text { Higher cytotoxicity in vitro and pronounced tumour regression effect in } \\
\text { vivo. }\end{array}$ & [150] \\
\hline RGD/NGR & $\mathrm{Pt}(\mathrm{IV})$ & Amide & $\begin{array}{l}\text { Cytotoxic to } \alpha_{v} \beta_{3} \text { and } \alpha_{v} \beta_{5} \text { expressing cell lines, approaching the } \\
\text { activity of cisplatin. }\end{array}$ & [104] \\
\hline
\end{tabular}




\section{Heparin-related hybrids}

Heparin is a highly sulphated natural polysaccharide, which is mainly composed of alternating units of sulphated glucuronic acid and glucosamine units. Heparin is well known for its anticoagulant activity, as well as for its interaction with growth factors including VEGF and basic fibroblast growth factor (bFGF) [151, 152]. Heparin treatment was formerly performed in a large number of clinical trials with cancer patients in order to treat venous thrombosis, leading to the suggestion that heparin also prolongs cancer patient survival [153]. Thus, heparin was found to inhibit angiogenesis and tumour progression and also to diminish metastasis by blocking selectin-mediated intercellular interactions [154-156], and by regulating various proteolytic enzymes essential for invasion of cancer cells and angiogenesis, through the ECM [153, 157].

However, due to its high anticoagulant effect which may induce haemorrhage as a side effect [158], heparin could only be administered at low concentration. Therefore, a number of heparin derivatives have been developed with non anticoagulant activity, while still maintaining their anti-angiogenic effects. A recent clinical trial has shown that low molecular weight heparins (LMWH) may provide an additional advantage in combination with chemotherapeutics, providing an increased tumour uptake and chemo-responsiveness in cancer patients [159]. It was proposed that the optimal anti-angiogenic activity of LMWH fractions varies between 3 and 6 kDa [160].

In contrast, Folkman et al. [161] have previously established that heparin alone could enhance tumour angiogenesis in the chorioallantoic membrane (CAM) assay. In a further extension of this work, it was noted that when the anti-inflammatory steroid cortisone was added the resultant combination suppressed background inflammation and inhibited angiogenesis, although cortisone alone had little or no effect. Several follow-on studies employing heparin as the basis of the scaffold have explored hybrid designs and these are now discussed in detail.

\section{HAH-cortisol hybrid}

The most closely related study to the above involved utilising a non anticoagulating derivative of heparin, namely heparin adipic hydrazide ( $\mathrm{HAH})$, which was linked by an acid-labile bond to cortisol (hydrocortisone). Although heparin receptors are present on other cell types, the majority of systemically administered heparin is taken up by vascular endothelial cells, which bind to sulphated polyanion receptors [162-164], and by cells of the reticuloendothelial system [165, 166] (possibly due to the vast surface area of these cells which are in contact with the blood). Dividing endothelial cells are more susceptible to heparin's effect as they bind and endocytose tenfold more heparin than non-dividing endothelial cells [167]. In this study, $\mathrm{HAH}$ and $\mathrm{HAH}$-cortisol conjugate $\mathbf{4}$ inhibited DNA synthesis by murine pulmonary capillary endothelial (MPCE) cells. The conjugate was more effective than the individual compounds either alone or in combination. HAH-cortisol slowed down the healing of wounded MPCE monolayer, and inhibited cell proliferation and migration. Neither the conjugate nor free HAH caused signs of toxicity when administered i.v. to mice at doses of $10 \mathrm{mg} /$ day for 14 days, unlike heparin and cortisol which were lethal at this dose. The anti-tumour effect of the conjugate and free drugs was examined in vivo by daily i.v. administration into animals bearing established subcutaneous (s.c.) Lewis lung carcinomas. Treatment with 4 showed highly significant retardation of tumour growth compared with cortisol alone or in combination with $\mathrm{HAH}$, whereas no reduction in tumour growth was observed with $\mathrm{HAH}$ alone [168].

\section{Heparin-carrying polystyrene conjugate}

Heparin-carrying polystyrene (HCPS) has been previously described as a synthetic glycoconjugate that has an amphiphilic structural unit consisting of hydrophilic polysaccharides and hydrophobic polystyrene moieties [169]. This conjugate showed a significantly reduced anticoagulant activity and was able to interact substantially with various heparin-binding growth factors known to stimulate angiogenesis, including FGF-2, VEGF 165 and hepatocyte growth factor (HGF) [170]. The effect of HCPS on cell growth was examined in growth factor-induced human dermal microvascular endothelial cells (HMVEC), and was found to inhibit growth in a dose-dependent manner, even at low concentrations ( $2 \mu \mathrm{g} / \mathrm{mL}$ ). Strong inhibition of tubular formation was noted following $2 \mu \mathrm{g} / \mathrm{mL}$ HCPS treatment of HMVEC seeded on matrigel, while anti-invasive activity and inhibition of cell adhesion were observed in Lewis lung carcinoma (3LL) and B16 mouse melanoma cells treated with $4 \mu \mathrm{g} / \mathrm{mL}$ of $\mathrm{HCPS}$. Treatment with HCPS showed a $40 \%$ reduction of $3 \mathrm{LL}$ tumours and $10 \%$ reduction of B16 tumours. Moreover, HCPS treatment reduced the number of CD34-positive vessels in Lewis lung carcinoma tumours and demonstrated anti-metastatic activity on both cancer cell lines, suggesting that this conjugate may be beneficial in a clinical setting [170]. The in vivo data obtained suggests there is merit in the use of this conjugate in the treatment of Lewis lung carcinoma.

\section{Heparin-DOCA conjugate}

In a separate study, a chemically modified heparin derivative, heparin-deoxycholic acid (HD) was designed by covalently coupling $\mathrm{N}$-deoxycholylethylenediamine (DOCA-NH2) to heparin to serve as a hydrophobic segment [171]. The resultant hybrid, termed a macromolecular aggregate, was shown to localise to tumour sites by the enhanced permeability and retention effect (EPR) [172]. The amide conjugate $\mathbf{5}$ was found to exhibit low anticoagulant activity and to form self-assembled nanoparticles in aqueous condition. During 5-bromo-2'-deoxyuridine (BrdU) incorporation assays, 5 inhibited HUVECS and SCC proliferation. The anti-angiogenic activity of $\mathbf{5}$ and heparin was examined using HUVECs layered onto matrigel-coated plates. The inhibitory effect of $100 \mu \mathrm{g} / \mathrm{mL}$ of $\mathbf{5}$ was more evident than heparin, as HUVECs gradually lost their intercellular contact. In order to test the ability of HD to inhibit bFGF-induced angiogenesis the matrigel plug assay was performed, where mice were injected s.c. with matrigel containing either bFGF, heparin or $\mathbf{5}$. After 10 days, the animals were sacrificed and matrigel plugs 
were excised, fixed and stained with either hematoxylin and eosin (H\&E) or CD31 antibody (microvessel staining). Matrigel plugs' haemoglobin content was reduced up to $82 \%$ by 5, indicating that HD effectively inhibited angiogenesis; however, neither heparin nor bFGF alone demonstrated any activity. The effect of $\mathbf{5}$ on the signal pathways (namely phosphorylation of FGFR, ERK and p38 MAPK) induced by bFGF was investigated. HUVECs were incubated with or without $\mathbf{5}$ in the presence or absence of bFGF and the phosphorylation of FGFR, ERK and p38 MAPK was analysed. The results suggested that 5 interacts with bFGF receptors and interferes with signalling pathways involving FGFR, ERK and p38 MAPK phosphorylation, thus suggesting a possible mechanisms by which $\mathbf{5}$ inhibits cell proliferation and angiogenesis. The results from the in vivo experiments showed that $\mathbf{5}$ inhibited tumour growth in tumour bearing mice in a dose-dependent manner [173]. The process of angiogenesis is complex and difficult to regulate; however these findings are encouraging because $\mathbf{5}$ demonstrated interaction with not only one but several signalling pathways, thus making it easier to modulate angiogenesis (Fig. 4).

Heparin adipic hydrazide $(\mathrm{HAH})$
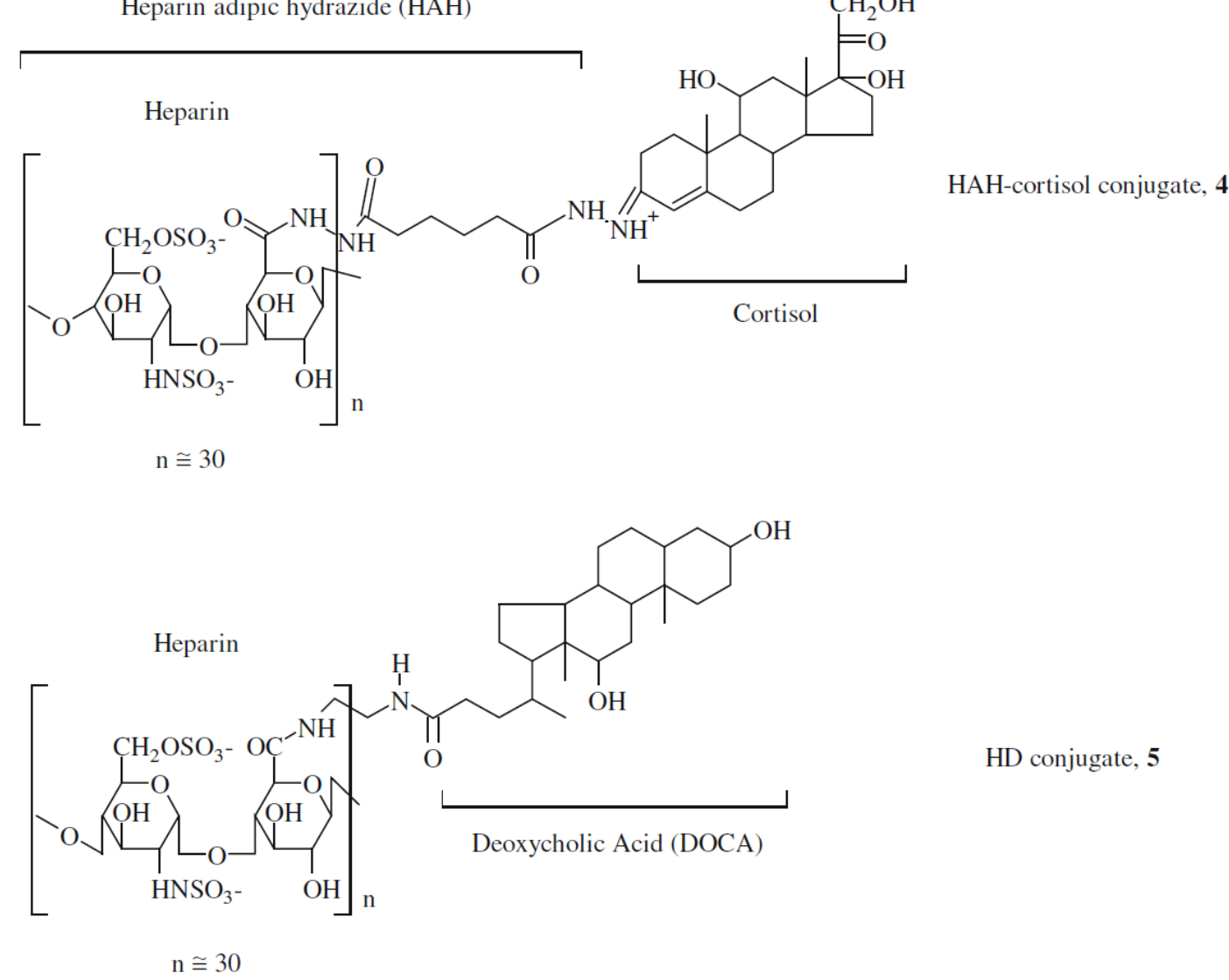

Figure 4 HAH-cortisol conjugate, 4 [168] and heparin-DOCA or HD conjugate, 5 [171, 173]. Heparin is a sulphated polysaccharide with repeating uronic acid and glucosamine residues that vary in number

An extension of this study involved loading DOX onto the amphiphilic HD conjugate in order to evaluate the use of this formulation in sustained drug release studies. DOX-loaded heparin nanoparticles (DHN) showed lower toxicity than free DOX. HD conjugate, DOX and DHN activity was evaluated in tumour bearing mice and the reduction in tumour volume was 43,56 and $74 \%$ respectively, confirming that DHN is more effective than the free agents and might provide a novel therapy for SCC [174]. The fact that DHN treatment showed a safer toxicological profile than free DOX reveals an additional advantage for this type of therapy.

\section{LMWH-DOCA conjugate}

Another conjugate, the orally active heparin derivative LHD, was synthesised by conjugating the carboxylic groups of LMWH to the carboxylic group of DOCA. Similar results were obtained when the anti-angiogenic effect of LHD and LMWH was examined in the capillary tube assay. The CAM assay was used to investigate the interaction between LMWH, LHD and bFGF. Although the effect of LMWH appeared smaller than LHD, the difference was not significant. The matrigel plug assay was performed and the haemoglobin contents of plugs from animals treated with LHD and LMWH versus untreated controls were $34.0 \pm 4.8$ and $102.3 \pm 7.2 \%$, respectively, suggesting that LHD reduced the haemoglobin content, whereas LMWH had no significant effect.

Microvessel density was also reduced by LHD treatment, but not by LMWH. The size of the tumours in SCC7 murine xenograft models was diminished with LHD treatment and the number of tumour microvessels decreased in a dosedependent manner. Combination therapy of LHD and DOX enhanced the anti-tumour effect in vivo compared to individual components, which suggests that this treatment may be a useful therapy for SCC [175, 176]. Additional studies revealed that LHD oral administration attenuated metastasis in B16F10 murine melanoma or A549 human lung carcinoma cells [177]. 
Moreover, LHD conjugates with further reduced anticoagulant activity were synthesised by controlling the DOCA coupling ratio, and showed inhibition of angiogenesis and tumour growth in SCC7 and A549 xenografts [178].

Additionally, a LMWH-taurocholate conjugate (LHT7) was synthesised and shown to have low anticoagulant activity, to bind to VEGF $_{165}$ more strongly $\left(\mathrm{K}_{d}\right.$ value: $\left.(3.21 \pm 0.04) \times 10^{-7} \mathrm{M}\right)$ than LMWH $\left(\mathrm{K}_{d}\right.$ value: $\left.(1.86 \pm 0.10) \times 10^{-5} \mathrm{M}\right)$ and to inhibit VEGFdependent kinase insert domain receptor (KDR) phosphorylation. When LHT7 was evaluated in the matrigel plug assay it showed a strong anti-angiogenic effect. In vivo efficacy studies resulted in a significant reduction in SCC7 tumour growth and increased survival rate [179].

\section{Folate-HL conjugate}

$\mathrm{Yu}$ et al. have designed low anticoagulant heparin amphiphiles: heparin-lithocholic acid conjugate (HL) and folateconjugated $\mathrm{HL}(\mathrm{FHL}, 6),[96]$. Folate receptors are over-expressed in various cancer types, including ovarian, endometrial, breast and colorectal cancers [180-183]. They have also been identified as markers of specific tumours for diagnostic and therapeutic purposes. In this study, $100 \mu \mathrm{g} / \mathrm{mL}$ of unfractionated heparin (UFH), HL and 6 were examined in the in vivo matrigel plug assay and the results showed that $\mathrm{HL}$ and $\mathbf{6}$ significantly inhibited plugs' vascularisation, where the haemoglobin content was reduced to 29 and $43 \%$, respectively. The effect of UFH was less than that of HL and 6, although still significant compared to the positive control. Cytotoxicity of the conjugates was evaluated in KB cervical adenocarcinoma cells using the 3-(4,5-dimethylthiazol-2-yl)-2,5-diphenyltetrazolium bromide (MTT) assay and showed that 6 reduced the viability of cells to $25 \%$ following $24 \mathrm{~h}$ incubation; HL had no effect on cell viability. FHL-treated cells induced sub- $\mathrm{G}_{1}$ phase accumulation (an indication of apoptosis) and induced a high amount of apoptotic cells after annexin V/propidium iodide (PI) staining, whereas UFH and HL had no effect. Cellular internalisation of HL and 6 in KB cells was investigated and $\mathbf{6}$ showed higher cellular uptake than $\mathrm{HL}$ indicating that folate conjugation provided the ability for cellular endocytosis. In vivo results revealed that both administered $\mathrm{HL}$ and $\mathbf{6}$ had similar anti-angiogenic activity and inhibitory effect on tumour growth; however FHL induced higher levels of apoptosis on tumour tissues [184]. The anti-angiogenic activity along with the apoptotic effects on cancer cells may provide an additional advantage for the evaluation of 6 in preclinical and clinical settings.
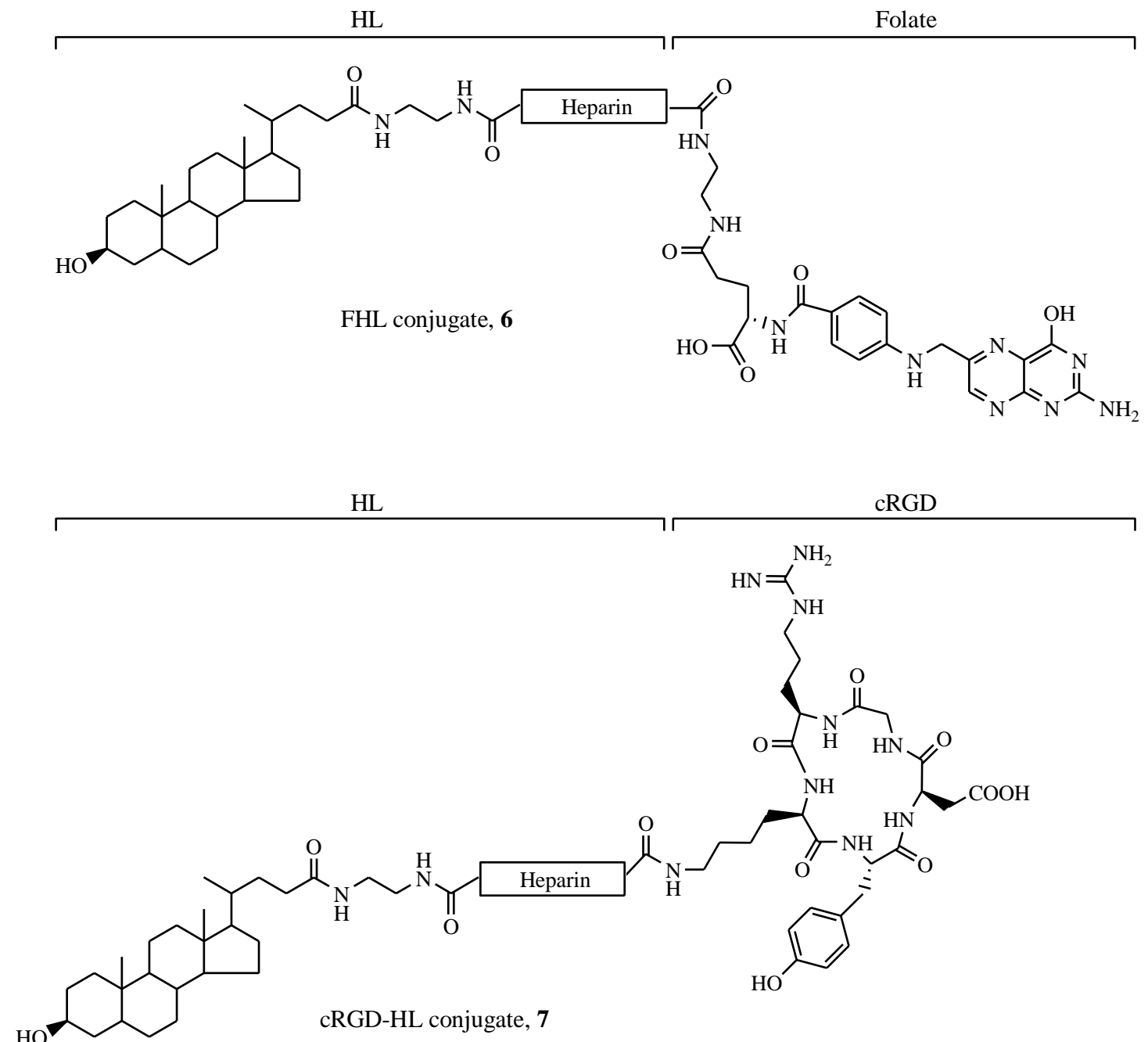

Figure 5 Folate-heparin-lithocholate (FHL) conjugate, 6 [184] and cRGD-heparin-lithocholic acid (cRGD-HL) conjugate, 7 [185] 
In a similar study, the investigators designed a cRGD-HL conjugate 7. Adhesion studies were performed using HUVECs. The addition of heparin, CRGDyK, $\mathrm{HL}$ and 7 decreased cell adhesion by 39.1, 45.0, 54.2 and $65.6 \%$, respectively. Additionally, the effect on cell migration was tested and was effectively reduced by $27.0 \%$ (heparin), $47.8 \%$ (cRGDyK), $72.1 \%$ (HL), and $82.8 \%$ (7). The inhibition of capillary tube formation was most profound in 7-treated cells, and where receptor binding studies have shown that 7 exhibited higher binding affinity for purified $\alpha_{v} \beta_{3}$ integrin, over cRGDyK. In the matrigel plug assay, 7 significantly inhibited bFGF-induced angiogenesis and tumour growth activity with superior anti-tumour effect for 7, compared to heparin and CRGDyK. The enhanced activity of the conjugate was suggested to be due to the anti-angiogenic characteristics of the heparin derivative (mediated through bFGF inhibition) and the additional effect from the integrinmediated interaction of the functionalised heparin derivative [185].

In summary, most of the heparin-related conjugates demonstrated significant differences in activity from their single components and co-administration of the individual components in a 1:1 ratio of the two. However, it is important that heparin analogues are properly examined for anticoagulant activity at an early stage, as well as at a more advanced in vivo setting, due to the fact that heparin conjugates could be metabolised into toxic analogues which may induce internal haemorrhage (Fig. 5; Table 2).

Table 2 Summary of the heparin-related hybrids

\begin{tabular}{|c|c|c|c|c|}
\hline Moiety A & Moiety B & Linker & Activity & References \\
\hline Heparin & Cortisone & - & Inhibition of angiogenesis and promising anti-tumour effect in vivo. & [161] \\
\hline $\mathrm{HAH}$ & Cortisol & Acid-labile bond & $\begin{array}{l}\text { Greater inhibition of DNA synthesis, MPCE cells' proliferation and } \\
\text { migration than either free compounds alone or in combination. } \\
\text { Significant retardation of tumour growth; no effect seen with cortisol } \\
\text { and } \mathrm{HAH} \text { or } \mathrm{HAH} \text { alone. }\end{array}$ & {$[168]$} \\
\hline Heparin & DOCA-NH $\mathrm{N}_{2}$ & Amide & $\begin{array}{l}\text { Inhibition of HUVECs' growth and angiogenesis in the matrigel plug } \\
\text { assay. Disruption of FGFR, ERK and p38 MAPK signalling pathways and } \\
\text { reduction of tumour growth. }\end{array}$ & {$[171,173]$} \\
\hline Heparin-DOCA & DOX & Amide & Reduced toxicity and higher anti-tumour activity in SCC than free agents. & {$[174]$} \\
\hline LMWH & DOCA & Anhydride & $\begin{array}{l}\text { Similar anti-angiogenic activity for the conjugate and LMWH. Reduced } \\
\text { microvessels and haemoglobin content in the matrigel plug assay by } \\
\text { the conjugate but not from LMWH or DOCA alone. Inhibition of } \\
\text { tumour growth in SCC-7 xenografts. }\end{array}$ & [175-178] \\
\hline LMWH & Taurocholate & Amide & $\begin{array}{l}\text { Angiogenesis inhibition was observed in the matrigel plug assay. } \\
\text { Significant reduction in SCC7 tumour growth and increased survival } \\
\text { rate after treatment with the conjugate. }\end{array}$ & {$[179]$} \\
\hline $\mathrm{HL}$ & Folate & Amide & $\begin{array}{l}\text { Reduction of KB cells' proliferation and induction of apoptosis. Inhibition } \\
\text { of vascularisation in the matrigel plug assay and anti-angiogenic } \\
\text { inhibition of tumour growth in vivo by both the conjugate and free HL. } \\
\text { Conjugate induced higher apoptosis in tumour tissue. }\end{array}$ & [184] \\
\hline $\mathrm{HL}$ & cRGD & Amide & $\begin{array}{l}\text { Inhibition of cell adhesion, migration and capillary tube formation of } \\
\text { HUVECs. Conjugate showed higher binding affinity for purified } \alpha_{v} \beta_{3} \\
\text { integrin than HL or cRGD. bFGF-induced angiogenesis was inhibited by } \\
\text { the conjugate and showed superior anti-tumour effect compared to } \\
\text { heparin and CRGD. }\end{array}$ & {$[185]$} \\
\hline
\end{tabular}

\section{Tubulin targeting cytotoxic hybrids}

Tubulin targeting cytotoxic hybrids have been designed to have one component which targets tubulin, either for antiangiogenic, anti-vascular or anti-tumour purposes, and another which serves as a cytotoxic agent. Early studies have involved linking a microtubule-targeting moiety with another anti-cancer agent which has a different target. For instance, Nakagawa-Goto et al. have designed different taxoid conjugates by linking various anti-cancer agents including glycyrrhetinic acid, colchicine, epipodophyllotoxin and camptothecin (CPT). PTX-CPT conjugates exhibited anti-angiogenic properties, as well as reduced inhibitory activity against normal human lung fibroblasts. Also, the PTX-CPT conjugates demonstrated higher anti-cancer activity against PC-3 and LN-CAP prostate cancer cells than PTX itself [186].

Another approach which has been exploited is the development of hybrids that link two tubulin targeting agents. For example, an admantane-based taxane-colchicine conjugate exhibited superior cytotoxicity against A549 adenocarcinomic human alveolar basal epithelial cells [187]. An additional colchicine-based hybrid was synthesised by its conjugation with caulerpenyne, a toxin isolated from the marine alga Caulerpa taxifolia [188], which exhibited inhibition of tubulin polymerisation and proliferation of SK-N-SH neuroblastoma cells [189]. The activity of the colchicine-caulerpenyne hybrid was disappointing against tubulin polymerisation, with an $\mathrm{IC}_{50}$ value $>100 \mu \mathrm{M}$. A high concentration $(10 \mu \mathrm{M})$ of the hybrid was required to inhibit more than $50 \%$ of the capillary network formation [190]. The fact that the hybrid demonstrated 
poor tubulin polymerisation activity, but still inhibited the capillary tube formation at $10 \mu \mathrm{M}$ may indicate that this was as a result of possible slow hydrolysis into different components. A re-evaluation on the concept of tubulin targeting agents in hybrid drugs is contained in a review by Breen and Walsh [105].

\section{Antibody-drug hybrids}

Despite the success of monoclonal antibodies in the clinic, naked antibodies targeting tumour associated antigens are mostly administered in combination with chemotherapy [191]. A relatively new approach is the development of antibodydrug conjugates which allows for the combination of the selectivity of monoclonal antibodies with the potency of cytotoxic drugs. This strategy aims to minimise systemic toxicity and to increase therapeutic efficacy. In fact, several studies demonstrated that antibody-drug conjugates enhanced the anti-tumour effect of naked antibodies and showed reduced systemic toxicity associated with the cytotoxic drugs conjugated to the antibody [192, 193].

\section{PTX-cetuximab hybrid}

As outlined above, tubulin targeting agents in particular have shown pronounced anti-vascular effects, but in certain situations have dose-limiting toxicities. To address this, antibody-drug conjugates have been synthesised which incorporate tubulin binding agents into the conjugate. This area has been extensively reviewed by Stack and Walsh [194]. For example, PTX has been used for such studies where it has been conjugated to a monoclonal antibody: cetuximab (a monoclonal antibody targeting EGFR). The in vitro cytotoxicity results indicated enhancement of the cytocidal effect of PTX as compared to that of the free drug, the intact antibody, and a physical mixture of the two. The in vivo anti-tumour activity of the conjugate was similar to that of cetuximab alone, which may be due to either a relatively low dose of the antibodydelivered drug $(346 \mu \mathrm{g} / \mathrm{kg})$ or extensive release of the conjugate into the circulation [195]. Although this conjugate was not directly investigated in an angiogenic setting, one would expect a direct anti-vascular effect from this hybrid, as the receptor involved is highly expressed on proliferating endothelial cells.

\section{Trastuzumab-DM1 hybrid}

The monoclonal antibody trastuzumab (which interferes with the HER2 receptor) has been conjugated with maytansinoid (DM1), a microtubule depolymerising agent. The resulting conjugate trastuzumab-DM1 (T-DM1) was designed to deliver DM1 into the human epidermal growth factor receptor 2 (HER2) over-expressing cells via receptor mediated endocytosis. In this way, inactivation of the HER2 receptors should result in inhibition of signalling cascades, including phosphoinositide 3-kinase (PI3 K)/Akt and MAPK pathways, which are associated with cell proliferation and angiogenesis. In addition, disruption of tumour vasculature and angiogenesis may also be mediated by the action of the tubulin binding component, DM1. T-DM1 conjugate has shown activity in both in vitro and in vivo models of trastuzumab-resistant breast cancer [196]. It has also shown remarkable activity in Phase I and II clinical trials in patients with trastuzumab-resistant HER2-expressing breast cancer [197, 198].

\section{Prostate specific membrane antigen (PSMA) conjugates}

Further studies with antibody conjugates were carried out using an antibody against PSMA. PSMA is a membrane glycoprotein that is predominantly expressed in the prostate and in the neovasculature of various solid tumours, indicating its relevance as a target of the tumour vasculature $[199,200]$. It is also present in the serum of prostate cancer patients $[201,202]$. The anti-PSMA antibody was conjugated to the tubulin binding agent MMAE, which is a synthetic analogue of dolastatin 10 [203]. The anti-PSMA-MMAE hybrid demonstrated selectivity towards PSMA-expressing cell lines and showed high in vivo activity in prostate tumour xenografts following an initial course of docetaxel therapy [204]. An additional example includes the anti-PSMA antibody huJ591, which was conjugated to various toxins and radionucleotides. The antiPSMA conjugate showed promising potential for prostate cancer therapy and other solid tumours [205].

\section{Cytokine fusion chimeras}

Immunotherapeutics not only include conjugation to cytotoxic drugs but also fusion to cytokines (cytokine fusion chimeras). A monoclonal antibody, L19, was developed targeting a tumour specific splice form of fibronectin, which is selectively expressed on the tumour vasculature within a variety of tumours [206]. In addition, several derivatives of L19 antibody were generated and showed preclinical and clinical efficacy by specifically targeting the tumour vasculature [207-210]. Furthermore, two high affinity human antibodies, G11 and F16, were shown to bind to the large isoform of tenascin-C, a type of ECM glycoprotein expressed in different types of connective tissues, with a prominent perivascular pattern [211]. The activity of G11 and F16 antibodies was evaluated in a U87 glioblastoma xenograft model and showed a significant antitumour effect, by demonstrating accumulation at the tumour site but not in other organs [212]. Gerber et al. [213] have summarised the recent developments of antibody-drug conjugates which target the tumour vasculature and outlined future directions in that field by indicating some potential targets.

\section{Toxin-drug hybrids}

Similarly to the monoclonal antibodies, immunotoxins have previously been designed by using chemical [214] or molecular [215] approaches and have proved effective against lymphomas and leukaemias [216]. However, disappointing clinical results were observed in carcinoma and melanoma patients, most probably because these conjugates permeate poorly and 
unevenly into solid tumours [215, 217]. Thus, designing toxin conjugates which selectively target the tumour microenvironment and in particular the tumour vasculature was of paramount importance. In parallel with this initiative, studies have been performed where toxins have been incorporated into hybrid designs.

\section{VEGF-toxin hybrids}

A different strategy to target the tumour vasculature directly was introduced by Ramakrishnan et al. [218] who reported that a toxin polypeptide linked to the $\mathrm{VEGF}_{165}$ isoform can be used to target VEGF receptors and to inhibit the proliferation of endothelial cells. In addition, the $\mathrm{VEGF}_{165}$-toxin conjugate demonstrated inhibition of angiogenesis in the chick CAM assay and reduced the tumour growth of ovarian tumour xenografts [219].

Once it had been identified that VEGF 165 binds to the neuropilin-1 receptor (NP-1) expressed on endothelial and tumour cells, as well as in adult heart and placenta [220, 221], a different VEGF isoform, VEGF ${ }_{121}$, was used for conjugation with toxins, which binds to VEGFR-2 but not NP-1 [222]. A truncated form of diphtheria toxin (DT385) which contains the catalytic and the translocation domain of diphtheria toxin but lacks the innate receptor-binding domain was employed as the effector molecule. In order to facilitate chemical conjugation with $V_{E G F} 121$, DT385 was genetically modified to incorporate a cysteine residue at the carboxyl terminus. The $\mathrm{VEGF}_{121}$-DT385 conjugate demonstrated selective inhibition of endothelial cell proliferation, angiogenesis and tumour growth in vivo, without apparent toxicity [223].

\section{Irofulven-anginex hybrid}

Irofulven (MGI-114; 6-hydroxymethylacylfulvene) is a leading member of the acylfulvenes, which are a semi-synthetic class of compounds derived from illudin S, a toxin produced by the Omphalotus illudens mushroom, which has demonstrated in vitro and in vivo anti-tumour activities. Irofulven has shown clinical activity against a variety of cancers, alone or in combination with other chemotherapeutic agents [224]. However, DLTs were observed including myelosuppresion, neutropenia, thrombocytopenia, nausea, vomiting and fatigue $[225,226]$. In order to reduce the systemic toxicity and maintain (or even improve) the clinical efficacy, irofulven was conjugated to anginex [227, 228], an anti-angiogenic agent which targets galectin-1 [229] (a cell surface glycan binding protein which is highly up-regulated in tumour-activated endothelial cells) [230, 231]. The irofulven-anginex conjugate demonstrated superior activity to that of equivalent doses of either compound alone, in an ovarian tumour xenograft model, and selectively targeted the tumour vasculature by inhibition of tumour angiogenesis. Interestingly, the conjugate has not shown apparent systemic toxicity unlike irofulven [232] (Table 3).

Table 3 Summary of the tubulin targeting-cytotoxic, antibody-drug and toxin-drug hybrids

\begin{tabular}{|c|c|c|c|}
\hline Moiety A & Moiety B & Activity & References \\
\hline \multicolumn{4}{|c|}{ Tubulin targeting-cytotoxic hybrids } \\
\hline PTX & CPT & $\begin{array}{l}\text { Hybrid exhibited anti-angiogenic properties and higher anti-cancer activity } \\
\text { against PC-3 and LN-CAP prostate cancer cells than PTX itself. }\end{array}$ & [186] \\
\hline Admantane-based taxane & Colchicine & $\begin{array}{l}\text { Hybrid exhibited superior cytotoxicity against A549 adenocarcinomic human } \\
\text { alveolar basal epithelial cells. }\end{array}$ & [187] \\
\hline Caulerpenyne & Colchicine & $\begin{array}{l}\text { Disappointing activity of hybrid against tubulin polymerisation with } I C_{50} \text { value } \\
>100 \mu \mathrm{M} \text {, whereas } 50 \mu \mathrm{M} \text { was required to inhibit more than } 50 \% \text { of the } \\
\text { formation of capillary network. }\end{array}$ & [190] \\
\hline \multicolumn{4}{|l|}{ Antibody-drug hybrids } \\
\hline PTX & Cetuximab & $\begin{array}{l}\text { Enhanced cytocidal effect of PTX compared to that of the free drug, the intact } \\
\text { antibody, and their 1:1 combination. Hybrid showed similar in vivo anti-tumour } \\
\text { activity to that of cetuximab alone. }\end{array}$ & [195] \\
\hline DM1 & Trastuzumab & $\begin{array}{l}\text { Demonstrated activity in in vitro and in vivo models and Phase I and II clinical } \\
\text { trials in patients with trastuzumab-resistant breast cancer. }\end{array}$ & [196-198] \\
\hline MMAE & Anti-PSMA & $\begin{array}{l}\text { Hybrid showed selectivity towards PSMA-expressing cell lines and high in vivo } \\
\text { activity in prostate tumour xenografts. }\end{array}$ & {$[204,205]$} \\
\hline \multicolumn{4}{|l|}{ Toxin-drug hybrids } \\
\hline DT385 toxin & VEGF $_{165}$ & $\begin{array}{l}\text { Hybrid displayed inhibition of angiogenesis in the CAM assay and reduced the } \\
\text { tumour growth of ovarian tumour xenografts. }\end{array}$ & [219] \\
\hline DT385 toxin & VEGF $_{121}$ & $\begin{array}{l}\text { Hybrid showed selective inhibition of endothelial cell proliferation, angiogenesis } \\
\text { and tumour growth in vivo, without apparent toxicity. }\end{array}$ & [223] \\
\hline Irofulven & Anginex & $\begin{array}{l}\text { Conjugate demonstrated superior activity to that of } 1: 1 \text { combination of single } \\
\text { agents, in an ovarian tumour xenograft model, and selectively targeted the } \\
\text { tumour vasculature. }\end{array}$ & [232] \\
\hline
\end{tabular}




\section{Conclusions}

The development of cancer is a complex process which depends on both intrinsic factors (i.e. gene expression, genetic mutation, cell adaptability) and on extrinsic signals sensed by the cell microenvironment (e.g. nutrient and metabolite gradient). Wherever there are solid tumours, there will be blood vessels to support the tumour growth. Although the majority of the approved anti-cancer agents so far are designed to target tumour cells directly, recent approaches aim to design drugs that indirectly kill cancer cells by targeting the tumour microenvironment and more specifically the tumour vasculature. The body of evidence introduced in this review indicates that the concept of hybrid/conjugate design is laudable and further research is encouraging. Emphasis should be placed on addressing the more aggressive, potentially metastatic and resistant cell lines, as well as on the poorly vascularised tumours where it is hard for therapeutic agents to reach. Furthermore, it is essential that both of the hybrid's components are evaluated individually and in physical combination at different ratios (e.g. 1:1, 1:2), in order to examine their activity and to reveal any advantages or disadvantages over the hybrid treatment. Several papers cited in this review have not established the effectiveness of the combination therapy and thus have not directly proven that the hybrid is more beneficial. The choice of the linker group should be carefully considered with regard to cleavability and also the possibility of metabolites' generation in vivo (which metabolites could mask the effect of the active component). It is also important to take into consideration the fact that the hybrid may terminate in a physiological environment. Conjugates that specifically aim to target cells over-expressing an angiogenic marker have also demonstrated activity and selectivity to tumour vasculature. However, the choice of the marker has to be cautiously considered and the expression pattern in normal and tumour tissue should be established.

As most FDA-approved anti-angiogenic agents are multi-targeted inhibitors of angiogenesis, such as sunitinib and sorafenib, more attention should be paid to the discovery of new compounds that possess dual or multi-inhibitory effect. However, resistance to such treatments is a common setback which can occur by a new mutation or by receptor down-regulation. In certain clinical trials, it is crucial to establish selection criteria (e.g. EGFR over-expression) for the participants prior to the initiation of the study, which may result in a successful treatment outcome, although this could be more costly and time consuming.

In conclusion, the body of data generated to date is encouraging and warrants further detailed studies into the development of novel hybrids targeting tumour angiogenesis/vasculature.

\section{References}

1. Hanahan D, Folkman J (1996) Patterns and emerging mechanisms of the angiogenic switch during tumorigenesis. Cell 86(3):353364. PMID: 8756718. DOI: 10.1016/S0092-8674(00)80108-7.

2. Bouck N, Stellmach V, Hsu SC (1996) How tumors become angiogenic. Adv Cancer Res 69:135-174. PMID: 8791681. DOI: 10.1016/S0065-230X(08)60862-3.

3. Gimbrone MA Jr, Leapman SB, Cotran RS, Folkman J (1972) Tumor dormancy in vivo by prevention of neovascularization. J Exp Med 136(2):261-276. PMID: 5043412. DOI: 10.1084/jem.136.2.261.

4. Ferrara N (2009) Vascular endothelial growth factor. Arterioscler Thromb Vasc Biol 29(6):789-791. PMID: 19164810. DOI: 10.1161/ATVBAHA.108.179663.

5. Mac Gabhann F, Popel AS (2008) Systems biology of vascular endothelial growth factors. Microcirculation 15(8):715-738. PMID: 18608994. DOI: 10.1080/10739680802095964.

6. Carmeliet P (2005) VEGF as a key mediator of angiogenesis in cancer. Oncology 69(Suppl 3):4-10. PMID: 16301830. DOI: $10.1159 / 000088478$.

7. Littlepage LE, Sternlicht MD, Rougier N, Phillips J, Gallo E, Yu Y, Williams K, Brenot A, Gordon JI, Werb Z (2010) Matrix metalloproteinases contribute distinct roles in neuroendocrine prostate carcinogenesis, metastasis, and angiogenesis progression. Cancer Res 70(6):2224-2234. PMID: 20215503. DOI: 10.1158/0008-5472.CAN-09-3515.

8. Pandya NM, Dhalla NS, Santani DD (2006) Angiogenesis - a new target for future therapy. Vascul Pharmacol 44(5):265-274. PMID: 16545987. DOI: 10.1016/j.vph.2006.01.005.

9. Kazerounian S, Yee KO, Lawler J (2008) Thrombospondins in cancer. Cell Mol Life Sci 65(5):700-712. PMID: 18193162. DOI: 10.1007/s00018-007-7486-z.

10. Vassalli JD, Sappino AP, Belin D (1991) The plasminogen activator/plasmin system. J Clin Invest 88(4):1067-1072. PMID: 1833420. DOI: $10.1172 / \mathrm{JCl} 115405$.

11. Wahl ML, Owen CS, Grant DS (2002) Angiostatin induces intracellular acidosis and anoikis in endothelial cells at a tumor-like low pH. Endothelium 9(3):205-216. PMID: 12380645. DOI: 10.1080/10623320213633.

12. O'Reilly MS, Holmgren L, Shing Y, Chen C, Rosenthal RA, Moses M, Lane WS, Cao Y, Sage EH, Folkman J (1994) Angiostatin: a novel angiogenesis inhibitor that mediates the suppression of metastases by a Lewis lung carcinoma. Cell 79(2):315-328. PMID: 7525077. DOI: 10.1016/0092-8674(94)90200-3.

13. O'Reilly MS (1997) Angiostatin: an endogenous inhibitor of angiogenesis and of tumor growth. EXS 79:273-294. PMID: 9002223. DOI: 10.1007/978-3-0348-9006-9_11.

14. Kurup A, Lin C, Murry DJ, Dobrolecki L, Estes D, Yiannoutsos CT, Mariano L, Sidor C, Hickey R, Hanna N (2006) Recombinant human angiostatin (rhAngiostatin) in combination with paclitaxel and carboplatin in patients with advanced non-small-cell lung cancer: a phase II study from Indiana University. Ann Oncol 17(1):97-103. PMID: 16282244. DOI: 10.1093/annonc/mdj055.

15. Gonzalez-Gronow M, Grenett HE, Fuller GM, Pizzo SV (1990) The role of carbohydrate in the function of human plasminogen: comparison of the protein obtained from molecular cloning and expression in Escherichia coli and COS cells. Biochim Biophys Acta 1039(3):269-276. PMID: 2198941. DOI: 10.1016/0167-4838(90)90259-I. 
16. DeMoraes ED, Fogler WE, Grant DS, Wahl ML, Leeper DB, Zrada S, Malin A, Connors S, Fortier AH, Dabrow M, Sidor C, Capizzi RL (2001) Recombinant Human Angiostatin (rhA): a Phase I Clinical Trial Assessing Safety, Pharmacokinetics (PK) and Pharmacodynamics (PD), in 2001 ASCO Annual Meeting, San Francisco, pp 12-15

17. Ling Y, Yang Y, Lu N, You QD, Wang S, Gao Y, Chen Y, Guo QL (2007) Endostar, a novel recombinant human endostatin, exerts antiangiogenic effect via blocking VEGF-induced tyrosine phosphorylation of KDR/Flk-1 of endothelial cells. Biochem Biophys Res Commun 361(1):79-84. PMID: 17644065. DOI: 10.1016/j.bbrc.2007.06.155.

18. O'Reilly MS, Boehm T, Shing Y, Fukai N, Vasios G, Lane WS, Flynn E, Birkhead JR, Olsen BR, Folkman J (1997) Endostatin: an endogenous inhibitor of angiogenesis and tumor growth. Cell 88(2):277-285. PMID: 9008168. DOI: 10.1016/S0092-8674(00)818486.

19. Folkman J (2006) Antiangiogenesis in cancer therapy-endostatin and its mechanisms of action. Exp Cell Res 312(5):594-607. PMID: 16376330. DOI: 10.1016/j.yexcr.2005.11.015.

20. Galligioni E, Ferro A (2001) Angiogenesis and antiangiogenic agents in non-small cell lung cancer. Lung Cancer 34(Suppl 4):S3-S7. PMID: 11742695. DOI: 10.1016/S0169-5002(01)00386-5.

21. Nyberg P, Xie L, Kalluri R (2005) Endogenous inhibitors of angiogenesis. Cancer Res 65(10):3967-3979. PMID: 15899784. DOI: 10.1158/0008-5472.CAN-04-2427.

22. Cao Y (2005) Tumor angiogenesis and therapy. Biomed Pharmacother 59(Suppl 2):S340-S343. PMID: 16507405. DOI: 10.1016/S0753-3322(05)80070-8.

23. Abdollahi A, Hlatky L, Huber PE (2005) Endostatin: the logic of antiangiogenic therapy. Drug Resist Updat 8(1-2):59-74. PMID: 15939343. DOI: 10.1016/j.drup.2005.03.001.

24. Wang J, Sun Y, Liu Y, Yu Q, Zhang Y, Li K, Zhu Y, Zhou Q, Hou M, Guan Z, Li W, Zhuang W, Wang D, Liang H, Qin F, Lu H, Liu X, Sun H, Luo S, Yang R, Tu Y, Wang X, Song S, Zhou J, You L, Yao C (2005) Results of randomized, multicenter, double-blind phase III trial of rhendostatin (YH-16) in treatment of advanced non-small cell lung cancer patients. Zhongguo Fei Ai Za Zhi 8(4):283-290. PMID: 21108883. DOI: 10.3779/j.issn.1009-3419.2005.04.07.

25. Cheng D, Liang B, Li Y (2012) Clinical value of vascular endothelial growth factor and endostatin in urine for diagnosis of bladder cancer. Tumori 98(6):762-767. PMID: 23389364. DOI: 10.1700/1217.13501.

26. Mo HY, Luo DH, Qiu HZ, Liu H, Chen QY, Tang LQ, Zhong ZL, Huang PY, Zhao ZJ, Zhang CQ, Zhang Y, Mai HQ (2013) Elevated serum endostatin levels are associated with poor survival in patients with advanced-stage nasopharyngeal carcinoma. Clin Oncol ( $R$ Coll Radiol) 25(5):308-17. PMID: 23290342. DOI: 10.1016/j.clon.2012.11.009.

27. Maeshima Y, Manfredi M, Reimer C, Holthaus KA, Hopfer H, Chandamuri BR, Kharbanda S, Kalluri R (2001) Identification of the antiangiogenic site within vascular basement membrane-derived tumstatin. J Biol Chem 276(18):15240-15248. PMID: 11278365. DOI: 10.1074/jbc.M007764200.

28. Sudhakar A, Sugimoto H, Yang C, Lively J, Zeisberg M, Kalluri R (2003) Human tumstatin and human endostatin exhibit distinct antiangiogenic activities mediated by alpha v beta 3 and alpha 5 beta 1 integrins. Proc Natl Acad Sci USA 100(8):4766-4771. PMID: 12682293. DOI: 10.1073/pnas.0730882100.

29. Sudhakar A, Boosani CS (2008) Inhibition of tumor angiogenesis by tumstatin: insights into signaling mechanisms and implications in cancer regression. Pharm Res 25(12):2731-2739. PMID: 18551250. DOI: 10.1007/s11095-008-9634-z.

30. Maeshima Y, Colorado PC, Torre A, Holthaus KA, Grunkemeyer JA, Ericksen MB, Hopfer H, Xiao Y, Stillman IE, Kalluri R (2000) Distinct antitumor properties of a type IV collagen domain derived from basement membrane. J Biol Chem 275(28):21340-21348. PMID: 10766752. DOI: 10.1074/jbc.M001956200.

31. Wang C, Li Q, Yao H, Liu M, Xiao Y, Jin D (2012) Anti-tumor peptide of tumstatin in the treatment of the transplantable model of human laryngeal squamous carcinoma in nude mice. Lin Chung Er Bi Yan Hou Tou Jing Wai Ke Za Zhi 26(6):277-279. PMID: 22675939.

32. Luo YQ, Ming Z, Zhao L, Yao LJ, Dong H, Du JP, Wu SZ, Hu W (2012) Decreased tumstatin-mRNA is associated with poor outcome in patients with NSCLC. IUBMB Life 64(5):423-431. PMID: 22473740. DOI: 10.1002/iub.1016.

33. Zhang GM, Sui LH, Jia T, Zhao YZ, Fu SB, Liu XH, Yu Y (2008) Inhibitory effect of recombinant anti-angiogenic peptide of tumstatin on growth and metastasis of human ovarian cancer transplanted in nude mice. Zhonghua Zhong Liu Za Zhi 30(3):170-173. PMID: 18756929.

34. Zhang GM, Zhang YM, Fu SB, Liu XH, Fu X, Yu Y, Zhang ZY (2008) Effects of cloned tumstatin-related and angiogenesis-inhibitory peptides on proliferation and apoptosis of endothelial cells. Chin Med J (Engl) 121(22):2324-2330. PMID: 19080341.

35. Thevenard J, Ramont L, Devy J, Brassart B, Dupont-Deshorgue A, Floquet N, Schneider L, Ouchani F, Terryn C, Maquart FX, Monboisse JC, Brassart-Pasco S (2010) The YSNSG cyclopeptide derived from tumstatin inhibits tumor angiogenesis by downregulating endothelial cell migration. Int J Cancer 126(5):1055-1066. PMID: 19551865. DOI: 10.1002/ijc.24688.

36. Kamphaus GD, Colorado PC, Panka DJ, Hopfer H, Ramchandran R, Torre A, Maeshima Y, Mier JW, Sukhatme VP, Kalluri R (2000) Canstatin, a novel matrix-derived inhibitor of angiogenesis and tumor growth. J Biol Chem 275(2):1209-1215. PMID: 10625665. DOI: $10.1074 / j b c .275 .2 .1209$.

37. Chung IS, Son YI, Ko YJ, Baek CH, Cho JK, Jeong HS (2008) Peritumor injections of purified tumstatin delay tumor growth and lymphatic metastasis in an orthotopic oral squamous cell carcinoma model. Oral Oncol 44(12):1118-1126. PMID: 18485794. DOI: 10.1016/j.oraloncology.2008.01.017.

38. He GA, Luo JX, Zhang TY, Hu ZS, Wang FY (2004) The C-terminal domain of canstatin suppresses in vivo tumor growth associated with proliferation of endothelial cells. Biochem Biophys Res Commun 318(2):354-360. PMID: 15120609. DOI: 10.1016/j.bbrc.2004.04.038.

39. Wang WB, Zhou YL, Heng DF, Miao CH, Cao YL (2008) Combination of tumor necrosis factor-related apoptosis-inducing ligand (TRAIL) and canstatin gene suppression therapy on breast tumor xenograft growth in mice. Breast Cancer Res Treat 110(2):283-295. PMID: 17899369. DOI: 10.1007/s10549-007-9731-4.

40. Panka DJ, Mier JW (2003) Canstatin inhibits Akt activation and induces Fas-dependent apoptosis in endothelial cells. J Biol Chem 278(39):37632-37636. PMID: 12876280. DOI: 10.1074/jbc.M307339200.

41. Hwang-Bo J, Yoo KH, Park JH, Jeong HS, Chung IS (2012) Recombinant canstatin inhibits angiopoietin-1-induced angiogenesis and lymphangiogenesis. Int J Cancer 131(2):298-309. PMID: 21823121. DOI: 10.1002/ijc.26353. 
42. Xing YN, Liang HW, Zhao L, Xu HM (2011) The antitumor activity of exogenous and endogenous canstatin on colorectal cancer cells. Asian Pac J Cancer Prev 12(10):2713-2716. PMID: 22320979.

43. North S, Moenner M, Bikfalvi A (2005) Recent developments in the regulation of the angiogenic switch by cellular stress factors in tumors. Cancer Lett 218(1):1-14. PMID: 15639335. DOI: 10.1016/j.canlet.2004.08.007.

44. Arbiser JL, Moses MA, Fernandez CA, Ghiso N, Cao Y, Klauber N, Frank D, Brownlee M, Flynn E, Parangi S, Byers HR, Folkman J (1997) Oncogenic H-ras stimulates tumor angiogenesis by two distinct pathways. Proc Natl Acad Sci USA 94(3):861-866. PMID: 9023347. DOI: pnas.94.3.861.

45. Ravi R, Mookerjee B, Bhujwalla ZM, Sutter CH, Artemov D, Zeng Q, Dillehay LE, Madan A, Semenza GL, Bedi A (2000) Regulation of tumor angiogenesis by p53-induced degradation of hypoxia-inducible factor 1alpha. Genes Dev 14(1):34-44. PMID: 10640274. DOI: 10.1101/gad.14.1.34.

46. Pasquale EB (2010) Eph receptors and ephrins in cancer: bidirectional signalling and beyond. Nat Rev Cancer 10(3):165-180. PMID: 20179713. DOI: $10.1038 / \mathrm{nrc2806}$.

47. Ahmed Z, Bicknell R (2009) Angiogenic signalling pathways. Methods Mol Biol 467:3-24. PMID: 19301662. DOI: 10.1007/978-159745-241-0_1.

48. Dejana E, Orsenigo F, Molendini C, Baluk P, McDonald DM (2009) Organization and signaling of endothelial cell-to-cell junctions in various regions of the blood and lymphatic vascular trees. Cell Tissue Res 335(1):17-25. PMID: 18855014. DOI: 10.1007/s00441008-0694-5.

49. Carmeliet P, Jain RK (2000) Angiogenesis in cancer and other diseases. Nature 407(6801):249-257. PMID: 11001068. DOI: 10.1038/35025220.

50. Dvorak HF, Nagy JA, Dvorak JT, Dvorak AM (1988) Identification and characterization of the blood vessels of solid tumors that are leaky to circulating macromolecules. Am J Pathol 133(1):95-109. PMID: 2459969. PMCID: PMC1880651.

51. Eberhard A, Kahlert S, Goede V, Hemmerlein B, Plate KH, Augustin HG (2000) Heterogeneity of angiogenesis and blood vessel maturation in human tumors: implications for antiangiogenic tumor therapies. Cancer Res 60(5):1388-1393. PMID: 10728704.

52. Kobayashi H, Tsuruchi N, Sugihara K, Kaku T, Saito T, Kamura T, Tsukamoto N, Nakano H, Taniguchi S (1993) Expression of alphasmooth muscle actin in benign or malignant ovarian tumors. Gynecol Oncol 48(3):308-313. PMID: 8462899. DOI: 10.1006/gyno.1993.1054.

53. Hashizume H, Baluk P, Morikawa S, McLean JW, Thurston G, Roberge S, Jain RK, McDonald DM (2000) Openings between defective endothelial cells explain tumor vessel leakiness. Am J Pathol 156(4):1363-1380. PMID: 10751361. DOI: 10.1016/S00029440(10)65006-7.

54. Paku S, Paweletz N (1991) First steps of tumor-related angiogenesis. Lab Invest 65(3):334-346. PMID: 1716330.

55. Baluk P, Morikawa S, Haskell A, Mancuso M, McDonald DM (2003) Abnormalities of basement membrane on blood vessels and endothelial sprouts in tumors. Am J Pathol 163(5):1801-1815. PMID: 14578181. DOI: 10.1016/S0002-9440(10)63540-7.

56. Less JR, Skalak TC, Sevick EM, Jain RK (1991) Microvascular architecture in a mammary carcinoma: branching patterns and vessel dimensions. Cancer Res 51(1):265-273. PMID: 1988088.

57. Gillies RJ, Schornack PA, Secomb TW, Raghunand N (1999) Causes and effects of heterogeneous perfusion in tumors. Neoplasia 1(3):197-207. PMID: 10935474. DOI: 10.1038/sj.neo.7900037.

58. Konerding MA, Malkusch W, Klapthor B, van Ackern C, Fait E, Hill SA, Parkins C, Chaplin DJ, Presta M, Denekamp J (1999) Evidence for characteristic vascular patterns in solid tumours: quantitative studies using corrosion casts. Br J Cancer 80(5-6):724-732. PMID: 10360650. DOI: 10.1038/sj.bjc.6690416.

59. Pasqualini R, Arap W, McDonald DM (2002) Probing the structural and molecular diversity of tumor vasculature. Trends Mol Med 8(12):563-571. PMID: 12470989. DOI: 10.1016/S1471-4914(02)02429-2.

60. Kelland LR (2005) Targeting established tumor vasculature: a novel approach to cancer treatment. Curr Cancer Ther Rev 1:1-9. DOI: $10.2174 / 1573394052952456$.

61. Hurwitz H, Fehrenbacher L, Novotny W, Cartwright T, Hainsworth J, Heim W, Berlin J, Baron A, Griffing S, Holmgren E, Ferrara N, Fyfe G, Rogers B, Ross R, Kabbinavar F (2004) Bevacizumab plus irinotecan, fluorouracil, and leucovorin for metastatic colorectal cancer. N Engl J Med 350(23):2335-2342. PMID: 15175435. DOI: 10.1056/NEJMoa032691.

62. Baselga J (2001) Clinical trials of Herceptin ${ }^{\circledR}$ (trastuzumab). Eur J Cancer 37(Suppl 1):S18-S24. PMID: 11167087. DOI: 10.1016/S0959-8049(00)00404-4.

63. Socinski MA, Novello S, Brahmer JR, Rosell R, Sanchez JM, Belani CP, Govindan R, Atkins JN, Gillenwater HH, Pallares C, Tye L, Selaru P, Chao RC, Scagliotti GV (2008) Multicenter, phase II trial of sunitinib in previously treated, advanced non-small-cell lung cancer. J Clin Oncol 26(4):650-656. PMID: 18235126. DOI: 10.1200/JCO.2007.13.9303.

64. Keating GM, Santoro A (2009) Sorafenib: a review of its use in advanced hepatocellular carcinoma. Drugs 69(2):223-240. PMID: 19228077. DOI: 10.2165/00003495-200969020-00006.

65. Pick AM, Nystrom KK (2012) Pazopanib for the treatment of metastatic renal cell carcinoma. Clin Ther 34(3):511-520. PMID: 22341567. DOI: 10.1016/j.clinthera.2012.01.014.

66. Gotink KJ, Verheul HM (2010) Anti-angiogenic tyrosine kinase inhibitors: what is their mechanism of action? Angiogenesis 13(1):114. PMID: 20012482. DOI: 10.1007/s10456-009-9160-6.

67. Nihei Y, Suzuki M, Okano A, Tsuji T, Akiyama Y, Tsuruo T, Saito S, Hori K, Sato Y (1999) Evaluation of antivascular and antimitotic effects of tubulin binding agents in solid tumor therapy. Jpn J Cancer Res 90(12):1387-1395. PMID: 10665658. DOI: 10.1111/j.13497006.1999.tb00724.x.

68. (1950) Colchicine in the chemotherapy of cancer. Br Med J 2(4681):718-719. PMID: 20787941. DOI: 10.1136/bmj.2.4681.718.

69. Hill SA, Lonergan SJ, Denekamp J, Chaplin DJ (1993) Vinca alkaloids: anti-vascular effects in a murine tumour. Eur J Cancer 29A(9):1320-1324. PMID: 8343277. DOI: 10.1016/0959-8049(93)90082-Q.

70. Wani MC, Taylor HL, Wall ME, Coggon P, McPhail AT (1971) Plant antitumor agents. VI. The isolation and structure of taxol, a novel antileukemic and antitumor agent from Taxus brevifolia. J Am Chem Soc 93(9):2325-2327. PMID: 5553076. DOI: 10.1021/ja00738a045.

71. Dutcher JP, Novik Y, O'Boyle K, Marcoullis G, Secco C, Wiernik PH (2000) 20th-century advances in drug therapy in oncology-Part. II. J Clin Pharmacol 40(10):1079-1092. PMID: 11028247. DOI: 10.1177/009127000004001002. 
72. Baguley BC, Holdaway KM, Thomsen LL, Zhuang L, Zwi L (1991) Inhibition of growth of colon 38 adenocarcinoma by vinblastine and colchicine: evidence for a vascular mechanism. Eur J Cancer 27(4):482-487. PMID: 1827725. DOI: 10.1016/0277-5379(91)90391-P.

73. Dark GG, Hill SA, Prise VE, Tozer GM, Pettit GR, Chaplin DJ (1997) Combretastatin A-4, an agent that displays potent and selective toxicity toward tumor vasculature. Cancer Res 57(10):1829-1834. PMID: 9157969.

74. Pettit GR, Cragg GM, Singh SB (1987) Antineoplastic agents, 122. Constituents of Combretum caffrum. J Nat Prod 50(3):386-391. PMID: 3668557. DOI: 10.1021/np50051a008.

75. Pettit GR, Temple C Jr, Narayanan VL, Varma R, Simpson MJ, Boyd MR, Rener GA, Bansal N (1995) Antineoplastic agents 322. synthesis of combretastatin A-4 prodrugs. Anticancer Drug Des 10(4):299-309. PMID: 7786396.

76. McGown AT, Fox BW (1989) Structural and biochemical comparison of the anti-mitotic agents colchicine, combretastatin A4 and amphethinile. Anticancer Drug Des 3(4):249-254. PMID: 2930627.

77. Tozer GM, Prise VE, Wilson J, Locke RJ, Vojnovic B, Stratford MR, Dennis MF, Chaplin DJ (1999) Combretastatin A-4 phosphate as a tumor vascular-targeting agent: early effects in tumors and normal tissues. Cancer Res 59(7):1626-1634. PMID: 10197639.

78. Murata R, Overgaard J, Horsman MR (2001) Comparative effects of combretastatin A-4 disodium phosphate and 5,6dimethylxanthenone-4-acetic acid on blood perfusion in a murine tumour and normal tissues. Int J Radiat Biol 77(2):195-204. PMID: 11236926. DOI: 10.1080/09553000010007695.

79. Tozer GM, Prise VE, Wilson J, Cemazar M, Shan S, Dewhirst MW, Barber PR, Vojnovic B, Chaplin DJ (2001) Mechanisms associated with tumor vascular shut-down induced by combretastatin A-4 phosphate: intravital microscopy and measurement of vascular permeability. Cancer Res 61(17):6413-6422. PMID: 11522635.

80. Kanthou C, Tozer GM (2002) The tumor vascular targeting agent combretastatin A-4-phosphate induces reorganization of the actin cytoskeleton and early membrane blebbing in human endothelial cells. Blood 99(6):2060-2069. PMID: 11877280. DOI: 10.1182/blood.V99.6.2060.

81. Stevenson JP, Rosen M, Sun W, Gallagher M, Haller DG, Vaughn D, Giantonio B, Zimmer R, Petros WP, Stratford M, Chaplin D, Young SL, Schnall M, O'Dwyer PJ (2003) Phase I trial of the antivascular agent combretastatin A4 phosphate on a 5-day schedule to patients with cancer: magnetic resonance imaging evidence for altered tumor blood flow. J Clin Oncol 21(23):4428-4438. PMID: 14645433. DOI: $10.1200 / J C O .2003 .12 .986$.

82. Dowlati A, Robertson K, Cooney M, Petros WP, Stratford M, Jesberger J, Rafie N, Overmoyer B, Makkar V, Stambler B, Taylor A, Waas J, Lewin JS, McCrae KR, Remick SC (2002) A phase I pharmacokinetic and translational study of the novel vascular targeting agent combretastatin a-4 phosphate on a single-dose intravenous schedule in patients with advanced cancer. Cancer Res 62(12):3408-3416. PMID: 12067983.

83. Rustin GJ, Galbraith SM, Anderson H, Stratford M, Folkes LK, Sena L, Gumbrell L, Price PM (2003) Phase I clinical trial of weekly combretastatin A4 phosphate: clinical and pharmacokinetic results. J Clin Oncol 21(15):2815-2822. PMID: 12807934. DOI: 10.1200/JCO.2003.05.185.

84. Mooney CJ, Nagaiah G, Fu P, Wasman JK, Cooney MM, Savvides PS, Bokar JA, Dowlati A, Wang D, Agarwala SS, Flick SM, Hartman PH, Ortiz JD, Lavertu PN, Remick SC (2009) A phase II trial of fosbretabulin in advanced anaplastic thyroid carcinoma and correlation of baseline serum-soluble intracellular adhesion molecule-1 with outcome. Thyroid 19(3):233-240. PMID: 19265494. DOI: 10.1089/thy.2008.0321.

85. Bottaro DP, Liotta LA (2003) Cancer: out of air is not out of action. Nature 423(6940):593-595. PMID: 12789320. DOI: 10.1038/423593a.

86. Tsuzuki Y, Fukumura D, Oosthuyse B, Koike C, Carmeliet P, Jain RK (2000) Vascular endothelial growth factor (VEGF) modulation by targeting hypoxia-inducible factor-1alpha--> hypoxia response element--> VEGF cascade differentially regulates vascular response and growth rate in tumors. Cancer Res 60(22):6248-6252. PMID: 11103778.

87. Yuan F, Chen Y, Dellian M, Safabakhsh N, Ferrara N, Jain RK (1996) Time-dependent vascular regression and permeability changes in established human tumor xenografts induced by an anti-vascular endothelial growth factor/vascular permeability factor antibody. Proc Natl Acad Sci USA 93(25):14765-14770. PMID: 8962129. DOI: 10.1073/pnas.93.25.14765.

88. Kadambi A, Mouta Carreira C, Yun CO, Padera TP, Dolmans DE, Carmeliet P, Fukumura D, Jain RK (2001) Vascular endothelial growth factor (VEGF)-C differentially affects tumor vascular function and leukocyte recruitment: role of VEGF-receptor 2 and host VEGF-A. Cancer Res 61(6):2404-2408. PMID: 11289105.

89. Lee CG, Heijn M, di Tomaso E, Griffon-Etienne G, Ancukiewicz M, Koike C, Park KR, Ferrara N, Jain RK, Suit HD, Boucher Y (2000) Anti-vascular endothelial growth factor treatment augments tumor radiation response under normoxic or hypoxic conditions. Cancer Res 60(19):5565-5570. PMID: 11034104.

90. Hansen-Algenstaedt N, Stoll BR, Padera TP, Dolmans DE, Hicklin DJ, Fukumura D, Jain RK (2000) Tumor oxygenation in hormonedependent tumors during vascular endothelial growth factor receptor-2 blockade, hormone ablation, and chemotherapy. Cancer Res 60(16):4556-4560. PMID: 10969807.

91. Carmeliet P, Jain RK (2011) Molecular mechanisms and clinical applications of angiogenesis. Nature 473(7347):298-307. PMID: 21593862. DOI: 10.1038/nature10144.

92. Weis SM, Cheresh DA (2011) Tumor angiogenesis: molecular pathways and therapeutic targets. Nat Med 17(11):1359-1370. PMID: 22064426. DOI: 10.1038/nm.2537.

93. Jain RK (2005) Normalization of tumor vasculature: an emerging concept in antiangiogenic therapy. Science 307(5706):58-62. PMID: 15637262. DOI: 10.1126/science.1104819.

94. Tozer GM, Kanthou C, Parkins CS, Hill SA (2002) The biology of the combretastatins as tumour vascular targeting agents. Int J Exp Pathol 83(1):21-38. PMID: 12059907. DOI: 10.1046/j.1365-2613.2002.00211.x.

95. Chaplin DJ, Pettit GR, Hill SA (1999) Anti-vascular approaches to solid tumour therapy: evaluation of combretastatin A4 phosphate. Anticancer Res 19(1A):189-195. PMID: 10226542.

96. Li L, Rojiani A, Siemann DW (1998) Targeting the tumor vasculature with combretastatin A-4 disodium phosphate: effects on radiation therapy. Int J Radiat Oncol Biol Phys 42(4):899-903. PMID: 9845118. DOI: 10.1016/S0360-3016(98)00320-4.

97. Horsman MR, Murata R, BreidahI T, Nielsen FU, Maxwell RJ, Stodkiled-Jorgensen H, Overgaard J (2000) Combretastatins novel vascular targeting drugs for improving anti-cancer therapy. Combretastatins and conventional therapy. Adv Exp Med Biol 476:311323. PMID: 10949676. DOI: 10.1007/978-1-4615-4221-6_26. 
98. Murata R, Siemann DW, Overgaard J, Horsman MR (2001) Improved tumor response by combining radiation and the vasculardamaging drug 5,6-dimethylxanthenone-4-acetic acid. Radiat Res 156(5 Pt 1):503-509. PMID: 11604063. DOI: 10.1667/00337587(2001)156[0503:ITRBCR]2.0.CO;2.

99. Dohn LH, Jensen BV, Larsen FO (2010) Short time infusion of bevacizumab in combination with 5FU-based chemotherapy as firstline therapy in a non-selective patient group with metastatic colorectal cancer. Acta Oncol 49(3):395-396. PMID: 20001495. DOI: 10.3109/02841860903428184.

100. Nathan P, Zweifel M, Padhani AR, Koh DM, Ng M, Collins DJ, Harris A, Carden C, Smythe J, Fisher N, Taylor NJ, Stirling JJ, Lu SP, Leach MO, Rustin GJ, Judson I (2012) Phase I trial of combretastatin A4 phosphate (CA4P) in combination with bevacizumab in patients with advanced cancer. Clin Cancer Res 18(12):3428-3439. PMID: 22645052. DOI: 10.1158/1078-0432.CCR-11-3376.

101. Walsh JJ, Bell A (2009) Hybrid drugs for malaria. Curr Pharm Des 15(25):2970-2985. PMID: 19754373. DOI: $10.2174 / 138161209789058183$.

102. Chow LM, Chan TH (2009) Novel classes of dimer antitumour drug candidates. Curr Pharm Des 15(6):659-674. PMID: 19199989. DOI: $10.2174 / 138161209787315576$

103. Kim JW, Lee HS (2004) Tumor targeting by doxorubicin-RGD-4C peptide conjugate in an orthotopic mouse hepatoma model. Int J Mol Med 14(4):529-535. PMID: 15375578.

104. Mukhopadhyay S, Barnes CM, Haskel A, Short SM, Barnes KR, Lippard SJ (2008) Conjugated platinum(IV)-peptide complexes for targeting angiogenic tumor vasculature. Bioconjug Chem 19(1):39-49. PMID: 17845003. DOI: 10.1021/bc070031k.

105. Breen EC, Walsh JJ (2010) Tubulin-targeting agents in hybrid drugs. Curr Med Chem 17(7):609-639. PMID: 20088764. DOI: $10.2174 / 092986710790416254$.

106. Rejniak KA, Anderson AR (2010) Hybrid models of tumor growth. Wiley Interdiscip Rev Syst Biol Med 3(1):115-125. PMID: 21064037. DOI: 10.1002/wsbm.102.

107. Aplin AE, Howe A, Alahari SK, Juliano RL (1998) Signal transduction and signal modulation by cell adhesion receptors: the role of integrins, cadherins, immunoglobulin-cell adhesion molecules, and selectins. Pharmacol Rev 50(2):197-263. PMID: 9647866.

108. Eliceiri BP, Cheresh DA (1999) The role of alphav integrins during angiogenesis: insights into potential mechanisms of action and clinical development. J Clin Invest 103(9):1227-1230. PMID: 10225964. DOI: 10.1172/JCI6869.

109. Enenstein J, Kramer RH (1994) Confocal microscopic analysis of integrin expression on the microvasculature and its sprouts in the neonatal foreskin. J Invest Dermatol 103(3):381-386. PMID: 8077704. DOI: 10.1111/1523-1747.ep12395390.

110. Brooks PC, Clark RA, Cheresh DA (1994) Requirement of vascular integrin alpha v beta 3 for angiogenesis. Science 264(5158):569571. PMID: 7512751 . DOI: 10.1126/science.7512751.

111. Brooks PC, Montgomery AM, Rosenfeld M, Reisfeld RA, Hu T, Klier G, Cheresh DA (1994) Integrin alpha v beta 3 antagonists promote tumor regression by inducing apoptosis of angiogenic blood vessels. Cell 79(7):1157-1164. PMID: 7528107. DOI: 10.1016/0092-8674(94)90007-8.

112. Storgard CM, Stupack DG, Jonczyk A, Goodman SL, Fox RI, Cheresh DA (1999) Decreased angiogenesis and arthritic disease in rabbits treated with an alphavbeta3 antagonist. J Clin Invest 103(1):47-54. PMID: 9884333. DOI: 10.1172/JCI3756.

113. Ruoslahti E (1996) RGD and other recognition sequences for integrins. Annu Rev Cell Dev Biol 12:697-715. PMID: 8970741. DOI: 10.1146/annurev.cellbio.12.1.697.

114. Cleaver O, Melton DA (2003) Endothelial signaling during development. Nat Med 9(6):661-668. PMID: 12778164. DOI: 10.1038/nm0603-661.

115. Pasqualini R, Koivunen E, Ruoslahti E (1997) Alpha v integrins as receptors for tumor targeting by circulating ligands. Nat Biotechnol 15(6):542-546. PMID: 9181576. DOI: 10.1038/nbt0697-542.

116. Felding-Habermann B, Mueller BM, Romerdahl CA, Cheresh DA (1992) Involvement of integrin alpha V gene expression in human melanoma tumorigenicity. J Clin Invest 89(6):2018-2022. PMID: 1376331. DOI: 10.1172/JCI115811.

117. Chen X, Plasencia C, Hou Y, Neamati N (2005) Synthesis and biological evaluation of dimeric RGD peptide-paclitaxel conjugate as a model for integrin-targeted drug delivery. J Med Chem 48(4):1098-1106. PMID: 15715477. DOI: 10.1021/jm049165z.

118. Janssen ML, Oyen WJ, Dijkgraaf I, Massuger LF, Frielink C, Edwards DS, Rajopadhye M, Boonstra H, Corstens FH, Boerman OC (2002) Tumor targeting with radiolabeled alpha(v)beta(3) integrin binding peptides in a nude mouse model. Cancer Res 62(21):6146-6151. PMID: 12414640.

119. Ryppa C, Mann-Steinberg H, Biniossek ML, Satchi-Fainaro R, Kratz F (2009) In vitro and in vivo evaluation of a paclitaxel conjugate with the divalent peptide E-[C(RGDfK)2] that targets integrin alpha v beta 3. Int J Pharm 368(1-2):89-97. PMID: 18992308. DOI: 10.1016/j.ijpharm.2008.09.055.

120. Temming K, Meyer DL, Zabinski R, Dijkers EC, Poelstra K, Molema G, Kok RJ (2006) Evaluation of RGD-targeted albumin carriers for specific delivery of auristatin E to tumor blood vessels. Bioconjug Chem 17(6):1385-1394. PMID: 17105215. DOI: $10.1021 / \mathrm{bc060087z.}$

121. Liu Y, Bajjuri KM, Liu C, Sinha SC (2012) Targeting cell surface alpha(v)beta(3) integrin increases therapeutic efficacies of a legumain protease-activated auristatin prodrug. Mol Pharm 9(1):168-175. PMID: 22044266. DOI: 10.1021/mp200434n.

122. Schiffelers RM, Ansari A, Xu J, Zhou Q, Tang Q, Storm G, Molema G, Lu PY, Scaria PV, Woodle MC (2004) Cancer siRNA therapy by tumor selective delivery with ligand-targeted sterically stabilized nanoparticle. Nucleic Acids Res 32(19):e149. PMID: 15520458. DOI: 10.1093/nar/gnh140.

123. Kunath K, Merdan T, Hegener O, Haberlein H, Kissel T (2003) Integrin targeting using RGD-PEl conjugates for in vitro gene transfer. J Gene Med 5(7):588-599. PMID: 12825198. DOI: 10.1002/jgm.382.

124. de Vries C, Escobedo JA, Ueno H, Houck K, Ferrara N, Williams LT (1992) The fms-like tyrosine kinase, a receptor for vascular endothelial growth factor. Science 255(5047):989-991. PMID: 1312256. DOI: 10.1126/science.1312256.

125. Kendall RL, Wang G, Thomas KA (1996) Identification of a natural soluble form of the vascular endothelial growth factor receptor, FLT-1, and its heterodimerization with KDR. Biochem Biophys Res Commun 226(2):324-328. PMID: 8806634. DOI: 10.1006/bbrc.1996.1355.

126. Boussif O, Lezoualc'h F, Zanta MA, Mergny MD, Scherman D, Demeneix B, Behr JP (1995) A versatile vector for gene and oligonucleotide transfer into cells in culture and in vivo: polyethylenimine. Proc Natl Acad Sci USA 92(16):7297-7301. PMID: 7638184. DOI: 10.1073/pnas.92.16.7297. 
127. Kim WJ, Yockman JW, Lee M, Jeong JH, Kim YH, Kim SW (2005) Soluble Flt-1 gene delivery using PEl-g-PEG-RGD conjugate for antiangiogenesis. J Control Release 106(1-2):224-234. PMID: 15970348. DOI: 10.1016/j.jconrel.2005.04.016.

128. Kim WJ, Yockman JW, Jeong JH, Christensen LV, Lee M, Kim YH, Kim SW (2006) Anti-angiogenic inhibition of tumor growth by systemic delivery of PEI-g-PEG-RGD/pCMV-sFlt-1 complexes in tumor-bearing mice. J Control Release 114(3):381-388. PMID: 16884805. DOI: 10.1016/j.jconrel.2006.05.029.

129. Curnis F, Sacchi A, Corti A (2002) Improving chemotherapeutic drug penetration in tumors by vascular targeting and barrier alteration. J Clin Invest 110(4):475-482. PMID: 12189241. DOI: 10.1172/JCI15223.

130. Fiers W (1995) Biologic therapy with TNF: preclinical studies. In Biologic Therapy of Cancer: Principles and Practice, ed. Lippincott. Philadelphia.

131. Fraker DL., Alexander HR, Pass HI (1995) Biologic therapy with TNF: systemic administration and isolation-perfusion. In Biologic Therapy of Cancer: Principles and Practice, ed. Lippincott. Philadelphia.

132. Pasqualini R, Koivunen E, Kain R, Lahdenranta J, Sakamoto M, Stryhn A, Ashmun RA, Shapiro LH, Arap W, Ruoslahti E (2000) Aminopeptidase $\mathrm{N}$ is a receptor for tumor-homing peptides and a target for inhibiting angiogenesis. Cancer Res 60(3):722-727. PMID: 10676659.

133. van Laarhoven HW, Gambarota G, Heerschap A, Lok J, Verhagen I, Corti A, Toma S, Gallo Stampino C, van der Kogel A, Punt CJ (2006) Effects of the tumor vasculature targeting agent NGR-TNF on the tumor microenvironment in murine lymphomas. Invest New Drugs 24(1):27-36. PMID: 16379040. DOI: 10.1007/s10637-005-4540-2.

134. Bordignon C, Caligaris Capio F, Toma S, Manenti L, Rizzardi P, Curnis F, Gallo Stampino C, Corti A (2006) NGRhTNF, a new vascular targeting agent with a dual mechanism of action: preliminary clinical results [abstract 13052]. J Clin Oncol 24(18S).

135. van Laarhoven HW, Fiedler W, Desar IM, van Asten JJ, Marreaud S, Lacombe D, Govaerts AS, Bogaerts J, Lasch P, Timmer-Bonte JN, Lambiase A, Bordignon C, Punt CJ, Heerschap A, van Herpen CM (2010) Phase I clinical and magnetic resonance imaging study of the vascular agent NGR-hTNF in patients with advanced cancers (European Organization for Research and Treatment of Cancer Study 16041). Clin Cancer Res 16(4):1315-1323. PMID: 20145168. DOI: 10.1158/1078-0432.CCR-09-1621.

136. Santoro A, Pressiani T, Citterio G, Rossoni G, Donadoni G, Pozzi F, Rimassa L, Personeni N, Bozzarelli S, Colombi S, De Braud FG, Caligaris-Cappio F, Lambiase A, Bordignon C (2010) Activity and safety of NGR-hTNF, a selective vascular-targeting agent, in previously treated patients with advanced hepatocellular carcinoma. Br J Cancer 103(6):837-844. PMID: 20717115. DOI: 10.1038/sj.bjc.6605858.

137. Mammoliti S, Andretta V, Bennicelli E, Caprioni F, Comandini D, Fornarini G, Guglielmi A, Pessino A, Sciallero S, Sobrero AF, Mazzola G, Lambiase A, Bordignon C (2010) Two doses of NGR-hTNF in combination with capecitabine plus oxaliplatin in colorectal cancer patients failing standard therapies. Ann Oncol 22(4):973-978. PMID: 20855468. DOI: 10.1093/annonc/mdq436.

138. Gregorc V, Santoro A, Bennicelli E, Punt CJ, Citterio G, Timmer-Bonte JN, Caligaris Cappio F, Lambiase A, Bordignon C, van Herpen CM (2009) Phase lb study of NGR-hTNF, a selective vascular targeting agent, administered at low doses in combination with doxorubicin to patients with advanced solid tumours. Br J Cancer 101(2):219-224. PMID: 19568235. DOI: 10.1038/sj.bjc.6605162.

139. Gregorc V, Zucali PA, Santoro A, Ceresoli GL, Citterio G, De Pas TM, Zilembo N, De Vincenzo F, Simonelli M, Rossoni G, Spreafico A, Grazia Vigano M, Fontana F, De Braud FG, Bajetta E, Caligaris-Cappio F, Bruzzi P, Lambiase A, Bordignon C (2010) Phase II study of asparagine-glycine-arginine-human tumor necrosis factor alpha, a selective vascular targeting agent, in previously treated patients with malignant pleural mesothelioma. J Clin Oncol 28(15):2604-2611. PMID: 20406925. DOI: 10.1200/JCO.2009.27.3649.

140. ClinicalTrials.gov. NGR015: Randomized double-blind Phase III study of NGR-hTNF Plus Best Investigator's Choice (BIC) Versus Placebo Plus BIC in previously treated patients with advanced malignant pleural mesothelioma (MPM). 2013; Available from: www.clinicaltrials.gov

141. Corti A, Ponzoni M (2004) Tumor vascular targeting with tumor necrosis factor alpha and chemotherapeutic drugs. Ann NY Acad Sci 1028:104-112. PMID: 15650236. DOI: 10.1196/annals.1322.011.

142. Tandle A, Hanna E, Lorang D, Hajitou A, Moya CA, Pasqualini R, Arap W, Adem A, Starker E, Hewitt S, Libutti SK (2009) Tumor vasculature-targeted delivery of tumor necrosis factor-alpha. Cancer 115(1):128-139. PMID: 19090007. DOI: 10.1002/cncr.24001.

143. Myers CE (1981) The pharmacology of the fluoropyrimidines. Pharmacol Rev 33(1):1-15. PMID: 6170079.

144. van Laar JA, Rustum YM, Ackland SP, van Groeningen CJ, Peters GJ (1998) Comparison of 5-fluoro-2'-deoxyuridine with 5fluorouracil and their role in the treatment of colorectal cancer. Eur J Cancer 34(3):296-306. PMID: 9640213. DOI: 10.1016/S09598049(97)00366-3.

145. Chu EMA, Fogarasi MC (2001) Pharmacology of cancer chemotherapy, 6 ed. In: DeVita VT (ed) Cancer principles and practice of oncology, ed. S.H.a.S.A.R, vol 1. Philadelphia

146. Zhang Z, Hatta H, Tanabe K, Nishimoto S (2005) A new class of 5-fluoro-2'-deoxyuridine prodrugs conjugated with a tumor-homing cyclic peptide CNGRC by ester linkers: synthesis, reactivity, and tumor-cell-selective cytotoxicity. Pharm Res 22(3):381-389. PMID: 15835743. DOI: 10.1007/s11095-004-1875-x.

147. Ndinguri MW, Solipuram R, Gambrell RP, Aggarwal S, Hammer RP (2009) Peptide targeting of platinum anti-cancer drugs. Bioconjug Chem 20(10):1869-1878. PMID: 19775102. DOI: 10.1021/bc900065r.

148. Temming K, Schiffelers RM, Molema G, Kok RJ (2005) RGD-based strategies for selective delivery of therapeutics and imaging agents to the tumour vasculature. Drug Resist Updat 8(6):381-402. PMID: 16309948. DOI: 10.1016/j.drup.2005.10.002.

149. Corti A, Curnis F, Arap W, Pasqualini R (2008) The neovasculature homing motif NGR: more than meets the eye. Blood 112(7):26282635. PMID: 18574027. DOI: 10.1182/blood-2008-04-150862.

150. Zhang YF, Wang JC, Bian DY, Zhang X, Zhang Q (2010) Targeted delivery of RGD-modified liposomes encapsulating both combretastatin A-4 and doxorubicin for tumor therapy: in vitro and in vivo studies. Eur J Pharm Biopharm 74(3):467-473. PMID: 20064608. DOI: 10.1016/j.ejpb.2010.01.002.

151. Lindahl U, Lidholt K, Spillmann D, Kjellen L (1994) More to “heparin” than anticoagulation. Thromb Res 75(1):1-32. PMID: 8073404. DOI: 10.1016/0049-3848(94)90136-8.

152. Soker S, Goldstaub D, Svahn CM, Vlodavsky I, Levi BZ, Neufeld G (1994) Variations in the size and sulfation of heparin modulate the effect of heparin on the binding of VEGF165 to its receptors. Biochem Biophys Res Commun 203(2):1339-1347. PMID: 7522446. DOI: $10.1006 /$ bbrc.1994.2329.

153. Zacharski LR, Ornstein DL (1998) Heparin and cancer. Thromb Haemost 80(1):10-23. PMID: 9684778. 
154. Mannori G, Crottet P, Cecconi O, Hanasaki K, Aruffo A, Nelson RM, Varki A, Bevilacqua MP (1995) Differential colon cancer cell adhesion to E-, P-, and L-selectin: role of mucin-type glycoproteins. Cancer Res 55(19):4425-4431. PMID: 7545541.

155. Borsig L, Wong R, Hynes RO, Varki NM, Varki A (2002) Synergistic effects of L- and P-selectin in facilitating tumor metastasis can involve non-mucin ligands and implicate leukocytes as enhancers of metastasis. Proc Natl Acad Sci USA 99(4):2193-2198. PMID: 11854515. DOI: 10.1073/pnas.261704098.

156. Borsig L (2004) Selectins facilitate carcinoma metastasis and heparin can prevent them. News Physiol Sci 19:16-21. PMID: 14739398. DOI: 10.1152/nips.01450.2003.

157. Engelberg $\mathrm{H}$ (1999) Actions of heparin that may affect the malignant process. Cancer 85(2):257-272. PMID: 10023691. DOI: 10.1002/(SICI)1097-0142(19990115)85:2<257::AID-CNCR1>3.0.CO;2-2.

158. Hirsh J (1984) Heparin induced bleeding. Nouv Rev Fr Hematol 26(4):261-266. PMID: 6382162.

159. Phillips PG, Yalcin M, Cui H, Abdel-Nabi H, Sajjad M, Bernacki R, Veith J, Mousa SA (2011) Increased tumor uptake of chemotherapeutics and improved chemoresponse by novel non-anticoagulant low molecular weight heparin. Anticancer Res 31(2):411-419. PMID: 21378319.

160. Rak J, Weitz JI (2003) Heparin and angiogenesis: size matters! Arterioscler Thromb Vasc Biol 23(11):1954-1955. PMID: 14617616. DOI: 10.1161/01.ATV.0000100563.16983.19.

161. Folkman J, Langer R, Linhardt RJ, Haudenschild C, Taylor S (1983) Angiogenesis inhibition and tumor regression caused by heparin or a heparin fragment in the presence of cortisone. Science 221(4612):719-725. PMID: 6192498. DOI: 10.1126/science.6192498.

162. Florey HW, Poole JC, Meek GA (1959) Endothelial cells and cement lines. J Pathol Bacteriol 77(2):625-636. PMID: 13642209. DOI: 10.1002/path.1700770234.

163. Hiebert LM, Jaques LB (1976) The observation of heparin on endothelium after injection. Thromb Res 8(2):195-204. PMID: 1251350. DOI: 10.1016/0049-3848(76)90262-0.

164. Mahadoo J, Heibert L, Jaques LB (1978) Vascular sequestration of heparin. Thromb Res 12(1):79-90. PMID: 644562. DOI: 10.1016/0049-3848(78)90087-7.

165. Schaefer C, Lo Bue J, Gollub S (1980) The biodistribution of exogenous [35S] heparin in the dog. Proc Soc Exp Biol Med 164(1):69-74. PMID: 7375475. DOI: 10.3181/00379727-164-40826.

166. Fabian I, Bleiberg I, Aronson M (1978) Increased uptake and desulphation of heparin by mouse macrophages in the presence of polycations. Biochim Biophys Acta 544(1):69-76. PMID: 718998. DOI: 10.1016/0304-4165(78)90210-6.

167. Sakamoto N, Tanaka NG (1988) Mechanism of the synergistic effect of heparin and cortisone against angiogenesis and tumor growth. Cancer J 2:9-16.

168. Thorpe PE, Derbyshire EJ, Andrade SP, Press N, Knowles PP, King S, Watson GJ, Yang YC, Rao-Bette M (1993) Heparin-steroid conjugates: new angiogenesis inhibitors with antitumor activity in mice. Cancer Res 53(13):3000-3007. PMID: 7686447.

169. Ishihara M, Saito Y, Yura H, Ono K, Ishikawa K, Hattori H, Akaike T, Kurita A (2000) Heparin-carrying polystyrene to mediate cellular attachment and growth via interaction with growth factors. J Biomed Mater Res 50(2):144-152. PMID: 10679678. DOI: 10.1002/(SICI)1097-4636(200005)50:2<144::AID-JBM8>3.0.CO;2-S.

170. Ishihara M, Ono K, Ishikawa K, Hattori H, Saito Y, Yura H, Akaike T, Ozeki Y, Tanaka S, Mochizuki H, Kurita A (2000) Enhanced ability of heparin-carrying polystyrene (HCPS) to bind to heparin-binding growth factors and to inhibit growth factor-induced endothelial cell growth. J Biochem 127(5):797-803. PMID: 10788788. DOI: 10.1093/oxfordjournals.jbchem.a022672.

171. Park K, Kim K, Kwon IC, Kim SK, Lee S, Lee DY, Byun Y (2004) Preparation and characterization of self-assembled nanoparticles of heparin-deoxycholic acid conjugates. Langmuir 20(26):11726-11731. PMID: 15595804. DOI: 10.1021/la048646i.

172. Maeda H, Wu J, Sawa T, Matsumura Y, Hori K (2000) Tumor vascular permeability and the EPR effect in macromolecular therapeutics: a review. J Control Release 65(1-2):271-284. PMID: 10699287. DOI: 10.1016/S0168-3659(99)00248-5.

173. Park K, Kim YS, Lee GY, Nam JO, Lee SK, Park RW, Kim SY, Kim IS, Byun Y (2007) Antiangiogenic effect of bile acid acylated heparin derivative. Pharm Res 24(1):176-185. PMID: 17109210. DOI: 10.1007/s11095-006-9139-6.

174. Park K, Lee GY, Kim YS, Yu M, Park RW, Kim IS, Kim SY, Byun Y (2006) Heparin-deoxycholic acid chemical conjugate as an anticancer drug carrier and its antitumor activity. J Control Release 114(3):300-306. PMID: 16884806. DOI: 10.1016/j.jconrel.2006.05.017.

175. Lee DY, Kim SK, Kim YS, Son DH, Nam JH, Kim IS, Park RW, Kim SY, Byun Y (2007) Suppression of angiogenesis and tumor growth by orally active deoxycholic acid-heparin conjugate. J Control Release 118(3):310-317. PMID: 17291620. DOI: 10.1016/j.jconrel.2006.12.031.

176. Lee Y, Nam JH, Shin HC, Byun Y (2001) Conjugation of low-molecular-weight heparin and deoxycholic acid for the development of a new oral anticoagulant agent. Circulation 104(25):3116-3120. PMID: 11748110. DOI: 10.1161/hc5001.100627.

177. Lee DY, Park K, Kim SK, Park RW, Kwon IC, Kim SY, Byun Y (2008) Antimetastatic effect of an orally active heparin derivative on experimentally induced metastasis. Clin Cancer Res 14(9):2841-2849. PMID: 18451252. DOI: 10.1158/1078-0432.CCR-07-0641.

178. Park JW, Jeon OC, Kim SK, Al-Hilal TA, Jin SJ, Moon HT, Yang VC, Kim SY, Byun Y (2010) High antiangiogenic and low anticoagulant efficacy of orally active low molecular weight heparin derivatives. J Control Release 148(3):317-326. PMID: 20869408. DOI: 10.1016/j.jconrel.2010.09.014.

179. Lee E, Kim YS, Bae SM, Kim SK, Jin S, Chung SW, Lee M, Moon HT, Jeon OC, Park RW, Kim IS, Byun Y, Kim SY (2009) Polyproline-type helical-structured low-molecular weight heparin (LMWH)-taurocholate conjugate as a new angiogenesis inhibitor. Int J Cancer 124(12):2755-2765. PMID: 19243020. DOI: 10.1002/ijc.24239.

180. Miotti S, Canevari S, Menard S, Mezzanzanica D, Porro G, Pupa SM, Regazzoni M, Tagliabue E, Colnaghi MI (1987) Characterization of human ovarian carcinoma-associated antigens defined by novel monoclonal antibodies with tumor-restricted specificity. Int J Cancer 39(3):297-303. PMID: 2434438. DOI: 10.1002/ijc.2910390306.

181. Coney LR, Tomassetti A, Carayannopoulos L, Frasca V, Kamen BA, Colnaghi MI, Zurawski VR Jr (1991) Cloning of a tumor-associated antigen: MOv18 and MOv19 antibodies recognize a folate-binding protein. Cancer Res 51(22):6125-6132. PMID: 1840502.

182. Weitman SD, Lark RH, Coney LR, Fort DW, Frasca V, Zurawski VR Jr, Kamen BA (1992) Distribution of the folate receptor GP38 in normal and malignant cell lines and tissues. Cancer Res 52(12):3396-3401. PMID: 1596899.

183. Parker N, Turk MJ, Westrick E, Lewis JD, Low PS, Leamon CP (2005) Folate receptor expression in carcinomas and normal tissues determined by a quantitative radioligand binding assay. Anal Biochem 338(2):284-293. PMID: 15745749. DOI: 10.1016/j.ab.2004.12.026. 
184. Yu MK, Lee DY, Kim YS, Park K, Park SA, Son DH, Lee GY, Nam JH, Kim SY, Kim IS, Park RW, Byun Y (2007) Antiangiogenic and apoptotic properties of a novel amphiphilic folate-heparin-lithocholate derivative having cellular internality for cancer therapy. Pharm Res 24(4):705-714. PMID: 17318418. DOI: 10.1007/s11095-006-9190-3.

185. Park K, Kim YS, Lee GY, Park RW, Kim IS, Kim SY, Byun Y (2008) Tumor endothelial cell targeted cyclic RGD-modified heparin derivative: inhibition of angiogenesis and tumor growth. Pharm Res 25(12):2786-2798. PMID: 18581207. DOI: 10.1007/s11095-0089643-y.

186. Nakagawa-Goto K, Nakamura S, Bastow KF, Nyarko A, Peng CY, Lee FY, Lee FC, Lee KH (2007) Antitumor agents. 256. Conjugation of paclitaxel with other antitumor agents: evaluation of novel conjugates as cytotoxic agents. Bioorg Med Chem Lett 17(10):28942898. PMID: 17350834. DOI: 10.1016/j.bmcl.2007.02.051.

187. Zefirova ON, Nurieva EV, Lemcke H, Ivanov AA, Shishov DV, Weiss DG, Kuznetsov SA, Zefirov NS (2008) Design, synthesis, and bioactivity of putative tubulin ligands with adamantane core. Bioorg Med Chem Lett 18(18):5091-5094. PMID: 18715782. DOI: 10.1016/j.bmcl.2008.07.116.

188. Amico V, Oriente G, Piattelli M, Tringali C, Fattorusso E, Magno S, Mayol L (1978) Caulerpenyne an unusual sesquiterpenoid from the green alga Caulerpa prolifera. Tetrahedron Lett 19(38):3593-3596. DOI: 10.1016/S0040-4039(01)95003-8.

189. Barbier P, Guise S, Huitorel P, Amade P, Pesando D, Briand C, Peyrot V (2001) Caulerpenyne from Caulerpa taxifolia has an antiproliferative activity on tumor cell line SK-N-SH and modifies the microtubule network. Life Sci 70(4):415-429. PMID: 11798011. DOI: 10.1016/S0024-3205(01)01396-0.

190. Bourdron J, Commeiras L, Barbier P, Bourgarel-Rey V, Pasquier E, Vanthuyne N, Hubaud JC, Peyrot V, Parrain JL (2006) Caulerpenyne-colchicine hybrid: synthesis and biological evaluation. Bioorg Med Chem 14(16):5540-5548. PMID: 16714115. DOI: 10.1016/j.bmc.2006.04.024.

191. Carter PJ, Senter PD (2008) Antibody-drug conjugates for cancer therapy. Cancer J 14(3):154-169. PMID: 18536555. DOI: 10.1097/PPO.0b013e318172d704.

192. Lambert JM (2005) Drug-conjugated monoclonal antibodies for the treatment of cancer. Curr Opin Pharmacol 5(5):543-549. PMID: 16087399. DOI: 10.1016/j.coph.2005.04.017.

193. Schrama D, Reisfeld RA, Becker JC (2006) Antibody targeted drugs as cancer therapeutics. Nat Rev Drug Discov 5(2):147-159. PMID: 16424916. DOI: $10.1038 / \mathrm{nrd} 1957$.

194. Stack GD, Walsh JJ (2012) Optimising the delivery of tubulin targeting agents through antibody conjugation. Pharm Res 29(11):2972-2984. PMID: 22777294. DOI: 10.1007/s11095-012-0810-9.

195. Safavy A, Bonner JA, Waksal HW, Buchsbaum DJ, Gillespie GY, Khazaeli MB, Arani R, Chen DT, Carpenter M, Raisch KP (2003) Synthesis and biological evaluation of paclitaxel-C225 conjugate as a model for targeted drug delivery. Bioconjug Chem 14(2):302310. PMID: 12643740 . DOI: 10.1021/bc020033z.

196. Lewis Phillips GD, Li G, Dugger DL, Crocker LM, Parsons KL, Mai E, Blattler WA, Lambert JM, Chari RV, Lutz RJ, Wong WL, Jacobson FS, Koeppen H, Schwall RH, Kenkare-Mitra SR, Spencer SD, Sliwkowski MX (2008) Targeting HER2-positive breast cancer with trastuzumab-DM1, an antibody-cytotoxic drug conjugate. Cancer Res 68(22):9280-9290. PMID: 19010901. DOI: 10.1158/00085472.CAN-08-1776.

197. Krop IE, Beeram M, Modi S, Jones SF, Holden SN, Yu W, Girish S, Tibbitts J, Yi JH, Sliwkowski MX, Jacobson F, Lutzker SG, Burris HA (2010) Phase I study of trastuzumab-DM1, an HER2 antibody-drug conjugate, given every 3 weeks to patients with HER2-positive metastatic breast cancer. J Clin Oncol 28(16):2698-2704. PMID: 20421541. DOI: 10.1200/JCO.2009.26.2071.

198. Burris HA 3rd, Rugo HS, Vukelja SJ, Vogel CL, Borson RA, Limentani S, Tan-Chiu E, Krop IE, Michaelson RA, Girish S, Amler L, Zheng M, Chu YW, Klencke B, O'Shaughnessy JA (2011) Phase II study of the antibody drug conjugate trastuzumab-DM1 for the treatment of human epidermal growth factor receptor 2 (HER2)-positive breast cancer after prior HER2-directed therapy. J Clin Oncol 29(4):398405. PMID: 21172893. DOI: 10.1200/JCO.2010.29.5865.

199. Silver DA, Pellicer I, Fair WR, Heston WD, Cordon-Cardo C (1997) Prostate-specific membrane antigen expression in normal and malignant human tissues. Clin Cancer Res 3(1):81-85. PMID: 9815541.

200. Haffner MC, Kronberger IE, Ross JS, Sheehan CE, Zitt M, Muhlmann G, Ofner D, Zelger B, Ensinger C, Yang XJ, Geley S, Margreiter R, Bander NH (2009) Prostate-specific membrane antigen expression in the neovasculature of gastric and colorectal cancers. Hum Pathol 40(12):1754-1761. PMID: 19716160. DOI: 10.1016/j.humpath.2009.06.003.

201. Bostwick DG, Grignon DJ, Hammond ME, Amin MB, Cohen M, Crawford D, Gospadarowicz M, Kaplan RS, Miller DS, Montironi R, Pajak TF, Pollack A, Srigley JR, Yarbro JW (2000) Prognostic factors in prostate cancer. College of American Pathologists Consensus Statement 1999. Arch Pathol Lab Med 124(7):995-1000. PMID: 10888774.

202. Liu H, Moy P, Kim S, Xia Y, Rajasekaran A, Navarro V, Knudsen B, Bander NH (1997) Monoclonal antibodies to the extracellular domain of prostate-specific membrane antigen also react with tumor vascular endothelium. Cancer Res 57(17):3629-3634. PMID: 9288760

203. Pettit GR (1997) The dolastatins. Fortschr Chem Org Naturst 70:1-79. PMID: 9088158. DOI: 10.1007/978-3-7091-6551-5_1.

204. Wang $X, M a D$, Olson WC, Heston WD (2011) In vitro and in vivo responses of advanced prostate tumors to PSMA ADC, an auristatin-conjugated antibody to prostate-specific membrane antigen. Mol Cancer Ther 10(9):1728-1739. PMID: 21750220. DOI: 10.1158/1535-7163.MCT-11-0191.

205. Milowsky MI, Nanus DM, Kostakoglu L, Sheehan CE, Vallabhajosula S, Goldsmith SJ, Ross JS, Bander NH (2007) Vascular targeted therapy with anti-prostate-specific membrane antigen monoclonal antibody J591 in advanced solid tumors. J Clin Oncol 25(5):540547. PMID: 17290063. DOI: 10.1200/JCO.2006.07.8097.

206. Castellani P, Viale G, Dorcaratto A, Nicolo G, Kaczmarek J, Querze G, Zardi L (1994) The fibronectin isoform containing the ED-B oncofetal domain: a marker of angiogenesis. Int J Cancer 59(5):612-618. PMID: 7525495. DOI: 10.1002/ijc.2910590507.

207. Viti F, Tarli L, Giovannoni L, Zardi L, Neri D (1999) Increased binding affinity and valence of recombinant antibody fragments lead to improved targeting of tumoral angiogenesis. Cancer Res 59(2):347-352. PMID: 9927045.

208. Tarli L, Balza E, Viti F, Borsi L, Castellani P, Berndorff D, Dinkelborg L, Neri D, Zardi L (1999) A high-affinity human antibody that targets tumoral blood vessels. Blood 94(1):192-198. PMID: 10381513. 
209. Borsi L, Balza E, Bestagno M, Castellani P, Carnemolla B, Biro A, Leprini A, Sepulveda J, Burrone O, Neri D, Zardi L (2002) Selective targeting of tumoral vasculature: comparison of different formats of an antibody (L19) to the ED-B domain of fibronectin. Int J Cancer 102(1):75-85. PMID: 12353237. DOI: 10.1002/ijc.10662.

210. Santimaria M, Moscatelli G, Viale GL, Giovannoni L, Neri G, Viti F, Leprini A, Borsi L, Castellani P, Zardi L, Neri D, Riva P (2003) Immunoscintigraphic detection of the ED-B domain of fibronectin, a marker of angiogenesis, in patients with cancer. Clin Cancer Res 9(2):571-579. PMID: 12576420.

211. Carnemolla B, Castellani P, Ponassi M, Borsi L, Urbini S, Nicolo G, Dorcaratto A, Viale G, Winter G, Neri D, Zardi L (1999) Identification of a glioblastoma-associated tenascin-C isoform by a high affinity recombinant antibody. Am J Pathol 154(5):13451352. PMID: 10329587. DOI: 10.1016/S0002-9440(10)65388-6.

212. Brack SS, Silacci M, Birchler M, Neri D (2006) Tumor-targeting properties of novel antibodies specific to the large isoform of tenascin-C. Clin Cancer Res 12(10):3200-3208. PMID: 16707621. DOI: 10.1158/1078-0432.CCR-05-2804.

213. Gerber HP, Senter PD, Grewal IS (2009) Antibody drug-conjugates targeting the tumor vasculature: current and future developments. MAbs 1(3):247-253. PMID: 20069754. DOI: 10.4161/mabs.1.3.8515.

214. Vitetta ES, Fulton RJ, May RD, Till M, Uhr JW (1987) Redesigning nature's poisons to create anti-tumor reagents. Science 238(4830):1098-1104. PMID: 3317828. DOI: 10.1126/science.3317828.

215. Pastan I, FitzGerald D (1991) Recombinant toxins for cancer treatment. Science 254(5035):1173-1177. PMID: 1683495. DOI: 10.1126/science.1683495.

216. Vitetta ES, Stone M, Amlot P, Fay J, May R, Till M, Newman J, Clark P, Collins R, Cunningham D, Ghetie V, Uhr JW, Thorpe PE (1991) Phase I immunotoxin trial in patients with B-cell lymphoma. Cancer Res 51(15):4052-4058. PMID: 1855219.

217. Vitetta ES, Thorpe PE (1991) Immunotoxins containing ricin or its A chain. Semin Cell Biol 2(1):47-58. PMID: 1954343.

218. Ramakrishnan S, Olson TA, Bautch VL, Mohanraj D (1996) Vascular endothelial growth factor-toxin conjugate specifically inhibits KDR/flk-1-positive endothelial cell proliferation in vitro and angiogenesis in vivo. Cancer Res 56(6):1324-1330. PMID: 8640821.

219. Olson TA, Mohanraj D, Roy S, Ramakrishnan S (1997) Targeting the tumor vasculature: inhibition of tumor growth by a vascular endothelial growth factor-toxin conjugate. Int J Cancer 73(6):865-870. PMID: 9399667. DOI: 10.1002/(SICI)10970215(19971210)73:6<865::AID-IJC17>3.0.CO;2-3.

220. Soker S, Fidder H, Neufeld G, Klagsbrun M (1996) Characterization of novel vascular endothelial growth factor (VEGF) receptors on tumor cells that bind VEGF165 via its exon 7-encoded domain. J Biol Chem 271(10):5761-5767. PMID: 8621443. DOI: 10.1074/jbc.271.10.5761.

221. Soker S, Gollamudi-Payne S, Fidder H, Charmahelli H, Klagsbrun M (1997) Inhibition of vascular endothelial growth factor (VEGF)induced endothelial cell proliferation by a peptide corresponding to the exon 7-encoded domain of VEGF165. J Biol Chem 272(50):31582-31588. PMID: 9395496. DOI: 10.1074/jbc.272.50.31582.

222. Gitay-Goren H, Cohen T, Tessler S, Soker S, Gengrinovitch S, Rockwell P, Klagsbrun M, Levi BZ, Neufeld G (1996) Selective binding of VEGF121 to one of the three vascular endothelial growth factor receptors of vascular endothelial cells. J Biol Chem 271(10):55195523. PMID: 8621410. DOI: 10.1074/jbc.271.10.5519.

223. Wild R, Dhanabal M, Olson TA, Ramakrishnan S (2000) Inhibition of angiogenesis and tumour growth by VEGF121-toxin conjugate: differential effect on proliferating endothelial cells. Br J Cancer 83(8):1077-1083. PMID: 10993657. DOI: 10.1054/bjoc.2000.1439.

224. Baekelandt M (2002) Irofulven (MGI Pharma). Curr Opin Investig Drugs 3(10):1517-1526. PMID: 12431030.

225. Eckhardt SG, Baker SD, Britten CD, Hidalgo M, Siu L, Hammond LA, Villalona-Calero MA, Felton S, Drengler R, Kuhn JG, Clark GM, Smith SL, MacDonald JR, Smith C, Moczygemba J, Weitman S, Von Hoff DD, Rowinsky EK (2000) Phase I and pharmacokinetic study of irofulven, a novel mushroom-derived cytotoxin, administered for five consecutive days every four weeks in patients with advanced solid malignancies. J Clin Oncol 18(24):4086-4097. PMID: 11118470.

226. Alexandre J, Raymond E, Kaci MO, Brain EC, Lokiec F, Kahatt C, Faivre S, Yovine A, Goldwasser F, Smith SL, MacDonald JR, Misset JL, Cvitkovic E (2004) Phase I and pharmacokinetic study of irofulven administered weekly or biweekly in advanced solid tumor patients. Clin Cancer Res 10(10):3377-3385. PMID: 15161692. DOI: 10.1158/1078-0432.CCR-03-0349.

227. Griffioen AW, van der Schaft DW, Barendsz-Janson AF, Cox A, Struijker Boudier HA, Hillen HF, Mayo KH (2001) Anginex, a designed peptide that inhibits angiogenesis. Biochem J 354(Pt 2):233-242. PMID: 11171099. DOI: 10.1042/0264-6021:3540233.

228. Dings RP, Mayo KH (2007) A journey in structure-based drug discovery: from designed peptides to protein surface topomimetics as antibiotic and antiangiogenic agents. Acc Chem Res 40(10):1057-1065. PMID: 17661438. DOI: 10.1021/ar700086k.

229. Thijssen VL, Postel R, Brandwijk RJ, Dings RP, Nesmelova I, Satijn S, Verhofstad N, Nakabeppu Y, Baum LG, Bakkers J, Mayo KH, Poirier F, Griffioen AW (2006) Galectin-1 is essential in tumor angiogenesis and is a target for antiangiogenesis therapy. Proc Natl Acad Sci USA 103(43):15975-15980. PMID: 17043243. DOI: 10.1073/pnas.0603883103.

230. Camby I, Le Mercier M, Lefranc F, Kiss R (2006) Galectin-1: a small protein with major functions. Glycobiology 16(11):137R-157R. PMID: 16840800 . DOI: $10.1093 / g l y c o b / c w l 025$.

231. Rabinovich GA (2005) Galectin-1 as a potential cancer target. Br J Cancer 92(7):1188-1192. PMID: 15785741. DOI: 10.1038/sj.bjc.6602493.

232. Dings RP, Van Laar ES, Loren M, Webber J, Zhang Y, Waters SJ, Macdonald JR, Mayo KH (2010) Inhibiting tumor growth by targeting tumor vasculature with galectin-1 antagonist anginex conjugated to the cytotoxic acylfulvene, 6-hydroxylpropylacylfulvene. Bioconjug Chem 21(1):20-27. PMID: 20020769. DOI: 10.1021/bc900287y. 